\title{
2 Distribution of Crustal Types in Canada Basin, Arctic Ocean
}

4 D. Chian ${ }^{5 *}$, H.R. Jackson ${ }^{1}$, D.R. Hutchinson ${ }^{2}$, J.W. Shimeld ${ }^{1}$, G.N. Oakey ${ }^{1}$, N. Lebedeva-Ivanova ${ }^{3}$,

$5 \quad$ Q. Li ${ }^{1}$, R.W. Saltus ${ }^{4}$, and D.C. Mosher ${ }^{1}$

$7 \quad *$ corresponding author

$8{ }^{1}$ Geological Survey of Canada Atlantic, 1 Challenger Dr. Box 1006 Dartmouth, N.S., B2Y 4A2

9 2U.S. Geological Survey, Woods Hole Science Center, 384 Woods Hole Rd., Woods Hole, MA 02543

$10{ }^{3}$ The Centre for Earth Evolution and Dynamics (CEED), University of Oslo, P.O. Box 1028 Blindern

110315 OSLO Norway

$12{ }^{4}$ United States Geological Survey, Mail Stop 964, Denver, CO 80225-0046

$13 \quad{ }^{5}$ Chian Consulting, 6238 Regina Terrace, Halifax, N.S., B3H 1N5, deping.chian@gmail.com

14

15 Abstract

16 Seismic velocities determined from 70 sonobuoys widely distributed in Canada Basin were used to

17 discriminate crustal types. Velocities of oceanic layer $3(6.7-7.1 \mathrm{~km} / \mathrm{s})$, transitional $(7.2-7.6 \mathrm{~km} / \mathrm{s})$ and

18 continental crust $(5.5-6.6 \mathrm{~km} / \mathrm{s})$ were used to distinguish crustal types. Potential field data supports the

19 distribution of oceanic crust as a polygon with maximum dimensions of $\sim 340 \mathrm{~km}$ (east-west) by $\sim 590 \mathrm{~km}$

20 (north-south) and identification of the ocean-continent boundary (OCB). Paired magnetic anomalies are

21 associated only with crust that has oceanic velocities. Furthermore, the interpreted top of oceanic crust

22 on seismic reflection profiles is more irregular and sometimes shallower than adjacent transitional crust. 
23 The northern segment of the narrow Canada Basin Gravity Low (CBGL), often interpreted as a spreading

24 centre, bisects this zone of oceanic crust and coincides with the location of a prominent valley in seismic

25 reflection profiles. Data coverage near the southern segment of CBGL is sparse. Velocities typical of

26 transitional crust are determined east of it. Extension in this region, close to the inferred pole of

27 rotation, may have been amagmatic. Offshore Alaska is a wide zone of thinned continental crust up to

$28300 \mathrm{~km}$ across. Published longer offset refraction experiments in the Basin confirm the depth to M oho

29 and the lack of oceanic layer 3 velocities. Further north, towards Alpha Ridge and along Northwind

30 Ridge, transitional crust is interpreted to be underplated or intruded by magmatism related to the

31 emplacement of the High Arctic Large Igneous Province (HALIP). Although a rotational plate tectonic

32 model is consistent with the extent of the conjugate magnetic anomalies that occupy only a portion of

33 Canada Basin, it does not explain the asymmetrical configuration of the oceanic crust in the deep water

34 portion of Canada Basin, and the unequal distribution of transitional and continental crust around the

35 basin.

36

\section{$37 \quad 1$ Introduction}

38 While most of the world's ocean basins have reliable dates to constrain their tectonic history, the

39 remote and ice-covered Canada Basin in the Arctic Ocean is enigmatic. The lack of clear magnetic

40 anomalies and the paucity of seismic profiles have allowed controversy to flourish on how Canada Basin

41 formed. Hypotheses about the nature of the crust underlying Canada Basin have ranged from

42 oceanization of the continental crust (Shatsky, 1935) to Paleozoic or Cretaceous ocean crust from the

43 Pacific (Churkin and Trexler, 1980) to M esozoic oceanic crust created through diverse (and often

44 conflicting) opening directions (Lawver and Scotese, 1990; Grantz et al., 2011; Døssing et al., 2013). On-

45 land geological similarities (Embry 1990) and recent detrital zircon studies (Gottlieb et al., 2014) permit 
46 the hypothesis that the Canadian Arctic Islands and northern Alaska were once contiguous but became

47 separated by the seafloor spreading that created Canada Basin. However, the models remain uncertain

48 because of overlaps and inconsistencies in the reconstruction models (e.g., Lawver and Scotese, 1990;

49 Lawver et al., 2002; Lane, 1997; Lane et al., 2015). One way to help resolve conflicts among these many

50 models and reconstructions is to identify crustal types and their distributions within Canada Basin.

51

52 Velocity characteristics of rocks can be used to distinguish and map distinct lithologic and crustal types,

53 such as oceanic crust (White et al., 1992). Between 2007 and 2011, Canadian and American

54 collaborators acquired wide angle reflection and refraction seismic data from 152 sonobuoys in the

55 Arctic Ocean primarily to study sedimentary velocities and depths and, where data quality enabled

56 longer source-to-receiver offsets to be analyzed, to also study the deeper basement and crustal

57 components. Of these, 87 sonobuoys are within Canada Basin and 70 are of sufficient quality to be used

58 in this study. Offsets up to $40 \mathrm{~km}$ allowed the velocities of crustal arrivals to be measured. In contrast

59 with older studies, the sonobuoy data were acquired with modern GPS navigation and digital recording

60 technology. These seismic data, because of their regional distribution, provide the opportunity for 3D

61 synthesis of velocities and crustal types on a basin-wide scale. This is a major difference from data

62 typically collected on high-resolution 2D transects of continental margins (e.g. Chian et al., 1999; White

63 et al., 2008; Funck et al., 2011). This paper presents the velocity synthesis of crustal layers, particularly

64 the distribution and nature of crustal types based on wide angle reflection/refraction sections, potential

65 field data, and coincident vertical incidence seismic reflection profiles. The newly defined distribution of

66 crustal types adds a new constraint on the formation of Canada Basin.

67 


\section{Geological Framework}

69 Canada Basin is a small ocean basin bordered on the south and east by the Alaskan and Beaufort Sea

70 and Canadian Arctic Islands continental margins respectively, on the west by Northwind Ridge of the

71 Chukchi Borderland, and on the north by Alpha Ridge (Fig. 1). The Alaskan, Beaufort and Canadian Arctic

72 Islands margins are sediment covered passive continental margins, although tectonic deformation

73 associated with the northeast extent of the Brooks Range deforms the southeastern Alaskan margin

74 (Helwig et al., 2011; Houseknecht and Bird, 2011). At the southeast corner of the basin, the Mackenzie

75 Delta/fan system extends for $\sim 350 \mathrm{~km}$ onto the seafloor to $\sim 3800 \mathrm{~m}$ water depth. The large structures

76 bounding Canada Basin are diverse. Northwind Ridge is a steep, linear escarpment rising $2800 \mathrm{~m}$ from

77 the abyssal sea floor. The southern edge of Alpha Ridge has irregular and occasionally steep

78 morphology. Between Northwind Ridge and Alpha Ridge lies the Nautilus Basin. Stefansson Basin forms

79 a similar semi-enclosed basin where the Canadian margin joins Alpha Ridge. This paper is restricted to

80 an interpretation of the crust in the region between the northern tip of Northwind Ridge and the

81 Canadian polar margin, south to Alaskan margin (Fig. 1).

82

83 The study of passive continental margins is relevant to understanding Canada Basin, because the

84 transition from continental to oceanic crust involves distinct changes in velocity structure, crustal

85 thickness, and reflection character, depending upon whether the passive margin is magma-rich (i.e.,

86 volcanic) or magma-poor (i.e., non- volcanic). A schematic cross-section (Fig. 2) shows the main

87 characteristics and distinguishing features of these end member crustal types. Commonly, a transition

88 zone is interpreted to separate oceanic from adjacent crustal types. The nomenclature for this zone has

89 been diverse, ranging from the simple (transition zone, e.g., Whitmarsh et al., 1993; Pickup et al., 1996)

90 to the complex (e.g., multiple domains of Sutra and M anatschal, 2012; Peron-Pinvidic et al., 2013).

91 Along some continental margins, this zone of transition is also sometimes called hyperextended 
92 (Whitmarsh et al., 2001; Sutra and M anatschal, 2012). The work by Lundin and Dore (2011) notes

93 confusion in using the term hyperextension because the term also refers to extended Early Cretaceous

94 rift basins that predate the early Cenozoic breakup of the North Atlantic, i.e., the origin of the

95 hyperextended crust is not necessarily from the final breakup process. Because the analysis in this

96 paper focuses on the extent of oceanic crust, rather than the full transects across the continental

97 margins, and in order to avoid confusion, we use the simplified terminology for thinned continental

98 crust, transitional crust, and oceanic crust (e.g. Chian et al., 1995; Pickup et al., 1996).

100 Oceanic crust is well known and remarkably consistent in its thickness, lithology, and geochemistry in 101 most of the world's oceans (e.g., White et al., 1992). White et al. (1992) pointed out that one of the 102 triumphs of early marine geophysics was recognizing the oceanic crustal structure being basically the 103 same everywhere. The two crustal layers beneath the sedimentary section have distinct and 104 characteristic velocities: layer 2 has variable velocities $(4.5-6.6 \mathrm{~km} / \mathrm{s})$, a large near-surface velocity 105 gradient $(\sim 1.0 / \mathrm{s})$, and a thickness of $\sim 2.1 \mathrm{~km}$; layer 3 has more consistent velocities $(6.7 \mathrm{~km} / \mathrm{s}$ but no 106 higher than $7.1 \mathrm{~km} / \mathrm{s}$ ), a smaller velocity gradient, and a thickness about twice that of layer 2 . Total 107 average thickness of normal oceanic crust for the North Atlantic is $7.08 \pm 0.78 \mathrm{~km}$ (White et al., 1992).

108 These values are consistent where oceanic spreading rates are greater than $20 \mathrm{~mm} / \mathrm{yr}$. Oceanic crust is 109 generally thinner along fracture zones and at slower rates of spreading, where melt is presumed to be 110 limited (Reid and Jackson, 1981; White et al., 1992).

112 The margins around the southern and central Canada Basin are inferred to be magma-poor

113 (nonvolcanic) passive margins based on the interpreted lack of rift-related volcanic activity in this region 114 (Grantz et al., 1979; Embry and Dixon, 1990; Hall, 1990; Sherwood, 1992; Houseknecht and Bird, 2011). 115 Off the southern Labrador margin, a similar magma-poor margin, the velocity of the continental crust is 
116 5.0-6.6 km/s (Chian et al., 1999). By analogy, the margins around southern Canada Basin are

117 characterized by velocities associated with continental crust or thinned continental crust, i.e., velocities

118 that are no higher than $\sim 6.6 \mathrm{~km} / \mathrm{s}$ and thicknesses that could range from $\sim 35$ to $<10 \mathrm{~km}$ (Stephenson et

119 al., 1994; Helwig et al., 2011).

120

121 In contrast, the northern Canadian polar margin near Alpha Ridge is interpreted as a magma-rich

122 (volcanic) rifted margin having thinned and intruded continental crust underlain by a high velocity layer

123 of $7.5-7.6 \mathrm{~km} / \mathrm{s}$ interpreted to be volcanic (Funck et al., 2011). Tholeiitic basalt flows and sills broadly

124 distributed across the Arctic are known on Ellesmere, Axel Heiberg, north Greenland and other polar

125 islands (Estrada and Henjes-Kunst, 2004; Tegner et al., 2011; Evenchick et al., 2015). Therefore, the

126 northern Canada Basin might be expected to contain thinned continental crust that changes into a zone

127 with features similar to magma-rich passive margins, i.e., seaward-dipping reflections associated with

128 extrusive subaerial and submarine basalt flows and a high-velocity intruded and underplated lower

129 crustal layer in which velocities are $7.4 \mathrm{~km} / \mathrm{s}$ or higher but less than upper mantle velocities of $\sim 8.0 \mathrm{~km} / \mathrm{s}$

130 (e.g. White et al., 2008).

131

132 High velocities are also associated with some magma-poor continental margins where serpentinized

133 upper mantle directly underlies the post-rift sedimentary section (Whitmarsh et al., 1993; 2001; Chian et

134 al., 1995; Pickup et al., 1996), similar to results off Iberia (e.g., Whitmarsh et al., 2000). This zone has

135 refraction velocities of 4.5-7.0 km/s from a 2-4 km thick upper layer overlying a lower layer with a

136 velocity of up to $7.6 \mathrm{~km} / \mathrm{s}$. These velocity models provide the analogs for which the velocities measured

137 in Canada Basin can be associated with different crustal types. 


\section{Methods}

\section{$140 \quad 3.1$ Data acquisition and processing}

141 The sound source for the wide angle reflection/ refraction data was an airgun array consisting of $2 \times 500$

142 and $1 \times 150 \mathrm{in}^{3}$ Sercel $^{\mathrm{TM}} \mathrm{G}$-guns totaling $1150 \mathrm{in}^{3}$. The airgun array was fired at a $14-20 \mathrm{~s}$ interval for an

143 average trace spacing of 20-30 $\mathrm{m}$. The receivers were Ultrasonic ${ }^{\mathrm{TM}}$ expendable sonobuoys with a single

144 hydrophone deployed at $60 \mathrm{~m}$ depth (or occasionally at $300 \mathrm{~m}$ depth). The seismic impulses were radio

145 telemetered back to the stacked Yagei $^{\mathrm{TM}}$ array on the ship. The sonobuoy signals were digitized onboard

146 ship and stored in SEGY format (e.g. M osher et al., 2013). All sonobuoy profiles and their interpretations

147 are documented in an atlas (Chian and Lebedeva-Ivanova, 2015).

149 Expendable sonobuoys do not have internal navigation systems; only the deployment position is known.

150 The direct arrival time used a water velocity profile for the sonobuoy hydrophone at $60 \mathrm{~m}$ depth

151 (Lebedeva-Ivanova and Lizaralde, 2011) to calculate the source to receiver offsets. Data processing of

152 sonobuoy wide angle reflection/refraction profiles includes a static time correction for airgun delay,

153 digitizing arrival time T (sec) of direct water wave for all traces, and assigning offsets (Chian and

154 Lebedeva-Ivanova, 2015). The refractions recorded in the sonobuoys traveled nearly horizontally in

155 corresponding layers, producing direct evidence for velocity measurements in sedimentary layers and

156 below. Nearly all sonobuoys in the central and southern Canada Basin had up to a dozen refractions

157 observed at source-receiver offsets of $9-40 \mathrm{~km}$. Since recordings spanned a wide range of frequencies,

158 final modeling used seismic data filtered at $2-50 \mathrm{~Hz}$ (in some cases non-filtered).

$160 \quad 3.2$ Modeling procedures

161 Forward modeling was accomplished using the RAYINVR program (Zelt and Smith 1992, Zelt and Forsyth

162 1994) and the in-house software of SeisWide (Chian and Lebedeva-Ivanova, 2015). Both the sonobuoy 
163 data and its coincident reflection profile (Chian and Lebedeva-Ivanova, 2015) were first geometrically

164 aligned in distance trace by trace. Major horizons on the reflection profile were digitized to generate a

165 preliminary model in the time domain. Each layer's velocity (V) and gradient should in general match the

166 corresponding refraction slope of the sonobuoy wide-angle data by $V=d X / d T$, which can be easily

167 measured. This time-domain model was converted to depth for raytracing using RAYINVR, and the

168 resulting travel-time curves were compared to the observed phases on the sonobuoy data. Such

169 comparison was greatly enhanced with NM O-reduced sonobuoy data (Chian and Lebedeva-Ivanova,

170 2015), especially when coincident reflection profile were available. The NM O-reduction aimed to

171 transform the data such that each wide-angle reflected phase at zero-offset matched exactly with the

172 reflection data. We found that, at the resolution of our experiment, whenever refracted phases were

173 properly modeled, we saw nearly perfect modeling for the corresponding wide-angle reflections. For

174 layers on reflection profile that were not associated with any sonobuoy refractions, a greater vertical

175 velocity gradient usually existed, which were modelled by matching the curvatures of the corresponding

176 sonobuoy wide-angle reflections. In general, a few perturbations of a layer velocity were usually

177 sufficient to arrive at a satisfactory match of the corresponding refraction phase. The process was used

178 for all layers. Since this method worked in the two-way time domain, only perturbations in velocity (not

179 time/depth) were needed because digitized reflection horizons were fixed during the model

180 perturbations. Note that in the sonobuoy profiles, the slopes of crustal refractions at farther offsets can

181 be easily identified where they became first arrivals, not entangled with reverberated and clustered

182 reflective energy. Seismic anisotropy was not considered due to its complexity, lack of sufficient ray

183 coverage in the relatively large study area. 


\subsection{Error Analysis}

186 Error analysis of the sonobuoy data for 5 main seismic refraction phases and upper mantle reflection 187 phase $(\mathrm{PmP})$ is summarized in Table 1. When picking each phase, every trace that contains visible 188 amplitudes was picked. The calculated uncertainties of the final model depend on the quality of the fit

189 between the calculated and the observed model. Two indicators of the reliability of the model are the 190 number of data points used to constrain the parameters of the layers, and the (root-mean-square) misfit

191 (Trms) between the calculated and observed travel times. Another indicator is the pick error bar of 40-

192200 ms assigned by visual inspection of the data, which was used to compute the normalized $X^{2}$ misfit.

193 In general a good fit was achieved partly due to the flat seafloor and low relief on the sedimentary

194 / crustal layers, relatively short offsets $(<35-40 \mathrm{~km}$ ), and the low ray coverage (no rays intersecting each

195 other). Because the sonobuoys do not overlap, the $X^{2}$ misfit compiled in Table 1 was better than some 196 other studies using overlapping seismometers such as Funck et al. (2011).

198 Table 1: Error analysis of selected sonobuoy velocities in Canada Basin (south of Alpha Ridge Igneous

199 Province), based on selected travel-time picks in continental (type 2), oceanic (type 3), and transitional

200 (type 4) zones. Type 1 includes other (unassigned) observed upper crustal picks that are used in this

201 study. Trms gives the root-mean-square misfit between calculated and picked travel times.

\begin{tabular}{|c|c|c|c|c|c|c|c|}
\hline Crustal Type & $\begin{array}{l}\text { Interval } \\
\text { Velocity } \\
(\mathrm{km} / \mathrm{s})\end{array}$ & $\begin{array}{l}\text { No. } \\
\text { of } \\
\text { SBs }\end{array}$ & $\begin{array}{l}\text { No. of } \\
\text { Picks } \\
\text { (total: } \\
\text { 18704) }\end{array}$ & Trms (s) & $\begin{array}{c}\text { Normalized } \\
x^{2}\end{array}$ & $\begin{array}{l}\text { Velocity } \\
\text { Error } \\
\text { Bound } \\
(\mathrm{km} / \mathrm{s})\end{array}$ & $\begin{array}{l}\text { Depth } \\
\text { Error } \\
\text { Bound } \\
(\mathrm{km})\end{array}$ \\
\hline $\begin{array}{l}\text { 1. Upper } \\
\text { (Unassigned) }\end{array}$ & $4.7 \leq V \leq 5.4$ & 6 & 1013 & 0.045 & 0.416 & \pm 0.2 & \pm 0.5 \\
\hline 2. Continental & $5.5 \leq \mathrm{V} \leq 6.6$ & 7 & 1154 & 0.041 & 0.259 & \pm 0.2 & \pm 1.0 \\
\hline
\end{tabular}




\begin{tabular}{|l|l|l|l|l|l|l|l|}
\hline 3. Oceanic & $6.7 \leq \mathrm{V} \leq 7.1$ & 24 & 4092 & 0.035 & 0.285 & \pm 0.2 & \pm 1.0 \\
\hline 4.Transitional & $7.2 \leq \mathrm{V} \leq 7.6$ & 28 & 5819 & 0.036 & 0.242 & \pm 0.2 & \pm 0.5 \\
\hline Upper mantle & $\mathrm{V} \geq 7.7$ & 13 & 1619 & 0.040 & 0.233 & \pm 0.1 & \pm 1.0 \\
\hline Moho & (PmP) & 22 & 5007 & 0.045 & 0.301 & & \\
\hline
\end{tabular}

203 To estimate the resolution of velocity models, the range of permissible variations in the models was

204 obtained by perturbing velocity values until the computed travel time curves cannot fit the observed

205 phases in both its slope and time. As described in Chian and Lebedeva-Ivanova (2015), the perturbation

206 of layer velocities was done in time domain in which we kept horizons unchanged in time based on

207 coincident reflection profile. For the layer of basement (upper crust in Table 1), the estimated depth

208 error bounds was a combination of errors caused by cumulative velocity errors of all overlying layers,

209 and interpretive (or phase pick) uncertainty on the reflection profiles and on the wide-angle data. Sub-

210 basement resolution estimates (error bounds in Table 1) were all based on wide-angle modeling as,

211 except in very few lines in the north (e.g. Figure 9), reflection data did not penetrate deeper than

212 basement.

\section{$214 \quad 3.4$ Crustal Classification}

215 Average sedimentary thicknesses throughout Canada Basin are $\sim 4-5 \mathrm{~km}$, and are much greater than

216 thicknesses found above ocean crust in most of the world's oceans (Divins, 2003). In the thickest

217 sedimentary deposits on Alaskan and Beaufort Sea margins, the deepest sedimentary rocks have

218 velocities of 4.7-4.9 km/s. Elsewhere in the basin, the sedimentary velocities generally increase from

$2191.8-1.9 \mathrm{~km} / \mathrm{s}$ to $3.5-4.2 \mathrm{~km} / \mathrm{s}$ at two way travel times of 3-4 s sub-seafloor. The base of the sedimentary

220 section was used as the top of the crust. The top was identified either by a high-impedance reflective

221 unconformity in the coincident multichannel seismic reflection profiles, or by the onset of velocities of 
$222-4.3-5.0 \mathrm{~km} / \mathrm{s}$ depending on location in Canada Basin. The sedimentary section is described in detail

223 elsewhere (Shimeld et al., 2016).

224

225 Immediately below the flat-lying sedimentary horizons is a layer generally less than $1 \mathrm{~km}$ thick that could

226 contain sedimentary as well as crystalline rocks. This layer consists of discontinuous dipping reflections,

227 locally bright continuous reflections containing unconformities, or widely spaced weak reflections. The

228 base of this unit generally forms acoustic basement, typically fading out of diffuse reflections or in

229 places with a distinct reflection. The velocity modeled in this layer is generally in the range of 4.2-4.4

$230 \mathrm{~km} / \mathrm{s}$. The top of this inferred basement unit is treated as the top of crust and may also represent

231 volcanic rocks interlayered with sedimentary deposits or Proterozoic or Paleozoic sedimentary strata

232 over basement or, in some locations, biogenic deposits. Thus, although the determination of the base of

233 sedimentary section is clear, the onset of the crust has an estimated uncertainty of up to $\pm 0.5 \mathrm{~km}$. 234

235 In order to derive an objective identification of crustal types, five velocity categories were assigned

236 attributes: continental, oceanic, and transitional crusts, as well as two undifferentiated categories

237 representing upper crust and upper mantle (Table 1 and Fig. 3). For oceanic crust there are two

238 exceptions near the spreading center discussed in section 4.1.1. Figure 3 shows the interpretation of

239 crustal types based on velocity. Upper crust and upper mantle velocities were not used in the

240 classification of most of the sonobuoys, exceptions are noted in sections 4.1.3.

241

242 In summary, we characterize thinned continental, transitional and oceanic crust from velocity ranges

243 outlined in Table 1. Each sonobuoy record is assigned a crustal type independently on this basis. In the

244 case where a sonobuoy recorded both continental and transitional velocities, it was categorized as

245 transitional crust, because transitional crust can include thinned continental crust (e.g. Whitmarsh et al., 
246 1996). For sonobuoys with both oceanic and transitional velocities of $7.3 \mathrm{~km} / \mathrm{s}$, other data were used to

247 interpret the crustal type (described in section 4.2.2.). The type categorization is extrapolated away

248 from the sonobuoys locations using coincident seismic reflection profiles and regional potential field

249 data. Finally, the potential field and bathymetry maps are used to assist in interpreting the boundaries

250 of the crustal types.

251

\section{Results}

\section{$253 \quad 4.1$ Sonobuoy data}

254 Of the 87 sonobuoys examined (Fig. 1), 27 were classified as oceanic, slightly more (30) as transitional,

255 and the fewest (13) as thinned continental crust. An additional 17 sonobuoys lacked information about

256 crustal type altogether, either because sedimentary section was too thick for crustal arrivals to be

257 measured (a case where crust is generally too stretched, fractured or broken such as in the Beaufort

258 Sea), noisy traces in the far offsets obscured the deeper arrivals or the recording ended prematurely

259 with no far offsets acquired. The velocity/depth profiles for continental, oceanic and transitional crust

260 are shown in Figures 3a, 3b, and 3c respectively. A sample sonobuoy record from each crustal type is

261 presented in Figures 4, 5, and 6. The sonobuoy names used in this paper are abbreviated from the

262 names listed in the Chian and Lebedeva-Ivanova (2015) atlas, i.e. SB LSL 2010-1 is shortened to SB 1001.

263

264 Because of the harsh ice conditions, project objectives and equipment failures, the sonobuoys were not

265 distributed evenly throughout Canada Basin (Fig. 1); the most consistent coverage is in the interior

266 portions of the basin. The continental margin off the Canadian Arctic Islands lacks robust crustal

267 information (only 2 sonobuoys); as well, there is a gap in the coverage where Northwind Ridge meets

268 Alaskan margin. Hence the sonobuoy data set is most representative of the deep-water portions of

269 Canada Basin. 
$271 \quad 4.1 .1$ Oceanic Crust (27 sonobuoys)

272 Roughly thirty percent of the sonobuoys in Canada Basin (i.e. 27) have crustal velocities in the range 6.7-

$2737.1 \mathrm{~km} / \mathrm{s}$, typical of oceanic layer 3 (Fig. 3b). Of these, 12 show mantle refractions (Pn) or less

274 commonly M oho reflections (PmP) with velocities generally of 8.0-8.1 km/s, with a range in velocities of $2757.7-8.2 \mathrm{~km} / \mathrm{s}$. These mantle arrivals constrain the thickness of oceanic crust to be 5-6 km, somewhat

276 thinner than typical oceanic crust of $\sim 7 \mathrm{~km}$ (White et al., 1992), and two have crust as thin as $4 \mathrm{~km}$.

277 These thicknesses are consistent with formation in slow spreading mid-ocean ridge settings (Bown and

278 White, 1994). The velocity/depth functions for these sonobuoys (Fig. 3b) favorably compare with those

279 observed in the North Atlantic slow spreading oceanic crust.

281 SB 0726 (Fig. 4) is representative of data from the oceanic region. The seismic reflection profile (Fig. 4a) 282 shows a change in the amplitude, frequency and continuity of the reflections at the base of the thick

283 flat-lying sedimentary section. The refracted arrivals at the base of this section have been interpreted to 284 have a velocity of $4.4 \mathrm{~km} / \mathrm{s}$. Beneath this layer a velocity of $4.7 \mathrm{~km} / \mathrm{s}$ is observed. This layer could 285 represent the upper part of oceanic layer 2 and might be composed of basalt flows intermixed with 286 sedimentary deposits. Refractions with velocities of between 5.4 and $6.3 \mathrm{~km} / \mathrm{s}$ are associated with the 287 upper layers of the crust. The above velocities are measured at the top of the layers and have high 288 velocity gradients typical of oceanic layer 2 . A clear $6.9 \mathrm{~km} / \mathrm{s}$ first arrival is observed over a $25-32 \mathrm{~km}$ 289 offset (Fig. 4b). At offsets of 33-39 km, a refraction with a velocity of $8.2 \mathrm{~km} / \mathrm{s}(\mathrm{Pn})$ is observed as the 290 first arrival. Crustal thickness is about $5.5 \mathrm{~km}$.

292 In the central Canada Basin, the majority of the sonobuoys results indicate oceanic crust. However, SB 2930804 and SB 0805 do not show well developed layer 3 velocities $(6.7-7.1 \mathrm{~km} / \mathrm{s})$ in the middle of the 
294 oceanic region (Figs. 1 and 7). The crustal velocities determined for these two sonobuoys are $6.6 \mathrm{~km} / \mathrm{s}$

295 (Fig. 3b) and $7.4 \mathrm{~km} / \mathrm{s}$ (Fig. 3c) respectively. The $6.6 \mathrm{~km} / \mathrm{s}$ velocity has an error bar of $\pm 2 \mathrm{~km} / \mathrm{s}$ and has 296 been plotted in the oceanic category. The $7.4 \mathrm{~km} / \mathrm{s}$ velocity requires assigning it to a transitional

297 category. Both of these are located close to the CBGL anomaly (Fig. 8) that has been interpreted to mark 298 the fossil spreading center (Laxon and M cAdoo, 1994). Velocity/ depth functions lacking layer 3 have 299 been observed in the vicinity of the ultra-slow spreading Gakkel Ridge (Jokat et al., 2003; Jokat and 300 Schmidt-Aursch, 2007; Hermann and Jokat, 2013) and also on the oblique (and ultraslow-spreading) 301 Knipovich Ridge (Kandilarov et al., 2010; Jokat et al., 2012). On the Knipovich Ridge, total crustal 302 thickness is anomalously thin $\sim 3.5-4.0 \mathrm{~km}$ and oceanic layer 3 has velocities of $5.7-6.1 \mathrm{~km} / \mathrm{s}$ and a Pn of

$3037 .-7.5 \mathrm{~km} / \mathrm{s}$. Crustal thickness on Knipovich Ridge increases to that more typical of oceanic crust at about $30440 \mathrm{~km}$ from the ridge axis where the first clear magnetic anomalies are observed. The relatively low 305 velocities in layer 3 are explained by thermal expansion of the young crust, fracturing and 306 serpentinization. White et al. (1992) also points out that in fracture zones, layer 3 is often absent. They

307 suggest the cause for this occurrence in fracture zone is that the melt has migrated laterally away 308 instead of being built up by multiple injections from below. As the spreading ceased at Canada Basin 309 ridge axis, a lack of melt could have also occurred, thus layer 3 would not be well developed and may 310 explain why these two sonobuoys are within the oceanic domain but do not have layer 3 velocities.

312 4.1.2 Transitional Crust (30 Sonobuoys)

313 There are 30 sonobuoys classified as transitional crust, with diagnostic velocities of 7.3-7.6 km/s. They 314 are geographically distributed around the oceanic crust (Fig. 1). Of these, 26 have velocities of 7.4-7.5 $315 \mathrm{~km} / \mathrm{s}$, and no velocities were higher than $7.5 \mathrm{~km} / \mathrm{s}$ (Fig. 3c). The original definition of transitional crust 316 has velocities in the range of $4.5-7.0 \mathrm{~km} / \mathrm{s}$ underlain by velocities of $7.6 \mathrm{~km} / \mathrm{s}$ that are associated with 
317 serpentinized mantle (e.g. Chian et al., 1995; Pickup et al., 1996). High-amplitude wide angle reflections

318 (PmP) are sometimes observed, providing constraints on crustal thickness.

320 SB 1034 and the coincident seismic reflection profile (Fig. 5) are representative of data from the

321 transitional crust. The sedimentary section on the coincident vertical incident seismic reflection profile

322 shows a thick section up to $6 \mathrm{~km}$ of flat-lying reflectors with a velocity of $<=4.5 \mathrm{~km} / \mathrm{s}$ (Fig. 5a). Beneath

323 the flat-lying horizons, a higher amplitude lower frequency hummocky reflection is observed. The layer

324 beneath this base sedimentary horizon has a $5.3 \mathrm{~km} / \mathrm{s}$ velocity and a thickness of $2.5 \mathrm{~km}$, based on

325 second arrivals. A clear first arrival refractor with a velocity of $7.4 \mathrm{~km} / \mathrm{s}$ is observed at the $25-35 \mathrm{~km}$

326 offsets Fig. 5b). This refractor has strong reverberations.

328 In the southeast part of Canada Basin in the Beaufort Sea, a group of sonobuoys are classified as 329 transitional (Figs. 1 and 3). These sonobuoys (SB 0710, Sb 0711, SB 1025, SB 1026, SB 1027, SB 1031, SB

3301032 , SB1033 and SB 1034, Fig. 5) have clear 4.3-4.5 km/s first arrivals that break over to 7.4-7.5 km/s.

331 The sedimentary section is greater than $10 \mathrm{~km}$ thick. Sedimentary velocities as high as $4.5 \mathrm{~km} / \mathrm{s}$ and a

332 single well-defined high-velocity layer of $7.5 \mathrm{~km} / \mathrm{s}$ (e.g. SB 1034) are characteristic of the region. The 7.4-

$3337.5 \mathrm{~km} / \mathrm{s}$ refractor is sometimes accompanied by a strong reverberatory band of wide angle reflection

334 energy, suggesting that the top of the high-velocity layer may be a sharp boundary. For models to match

335 the curve of the deepest wide angle reflections, masked layers with velocities in the range of $5.4 \mathrm{~km} / \mathrm{s}$

336 and $6.2 \mathrm{~km} / \mathrm{s}$ are required for SB 1027 and SB 1032 respectively (Fig. 3c). It suggests that continental

337 crust of less than a few kilometers thick exists in this region. On SB 1026 (Fig. 3c), the thick sedimentary

338 deposits may rest directly on the $7.5 \mathrm{~km} / \mathrm{s}$ layer and the crust may be absent. 
340 North of the Alaska margin along Northwind Ridge, velocities interpreted on SB 0722, SB 1013 and

341 SB1014 indicate that thin (continental) crustal layers may also be present (Figs. 1 and 3c). On SB 0722 a

$3426.1 \mathrm{~km} / \mathrm{s}$ upper continental crustal velocity lies immediately above the $7.5 \mathrm{~km} / \mathrm{s}$ layer. Nearby and

343 closer to Northwind Ridge, SB 1013 (Fig.1 and 3c) has well developed base of sedimentary section

344 arrivals and a weak $5.0 \mathrm{~km} / \mathrm{s}$ refractor overlying a $7.4 \mathrm{~km} / \mathrm{s}$ event and a possible weak Pn arrival that

345 would limit the depth to M oho to $17 \mathrm{~km}$. SB 1014 to the north of these sonobuoys and adjacent to

346 Northwind Ridge has crustal velocities in the range of, $6.0-6.6$ km/s overlying $7.4 \mathrm{~km} / \mathrm{s}$. SB 1015 slightly

347 to the east records a $6.3 \mathrm{~km} / \mathrm{s}$ layer overlying a $7.4 \mathrm{~km} / \mathrm{s}$ refractor with an associated weak PmP arrival.

348 This velocity range of above $7.4-7.5 \mathrm{~km} / \mathrm{s}$ is compatible with an earlier result of Jackson et al. (1995) in

349 the same area, suggesting that extremely thin, heterogeneous and possibly continental crust is a

350 common character of this transitional zone in deep water near Northwind Ridge.

351

352 4.1.3 Thinned Continental Crust (13 sonobuoys)

353 Thirteen sonobuoys are classified as thinned continental crust and most have velocities of 5.5-6.6 km/s

354 with no evidence of a higher velocity $7.2-7.6 \mathrm{~km} / \mathrm{s}$ deep layer (Fig. 3a). Six of these sonobuoys show

355 strong PmP wide angle reflections indicative of an abrupt change in velocity at the crust-mantle 356 interface.

358 SB 1003 with its coincident reflection profile (Fig. 6), located $260 \mathrm{~km}$ north of Alaskan margin, is an 359 example of data displaying continental velocities. On the accompanying seismic reflection record, a 360 thick sedimentary section ( $>6 \mathrm{~km}$ ) with horizontal reflections is observed. Arrivals as high as $4.7 \mathrm{~km} / \mathrm{s}$

361 (Fig. 6a) are attributed to the sedimentary section based on comparison with the accompanying seismic 362 reflection profile. Basement relief exists with draped high amplitude reflections filling in between these 363 basement highs. Unfortunately, the seismic reflection profile does not have the resolution to determine 
364 whether these highs are rotated fault blocks or merely basement highs. On the sonobuoy record (Fig.

365 6b), first arrivals of $6.0 \mathrm{~km} / \mathrm{s}$ are observed over the $20-27 \mathrm{~km}$ offsets. A second arrival exhibits a 6.3

$366 \mathrm{~km} / \mathrm{s}$ event (Fig. $6 \mathrm{~b}$ and $6 \mathrm{~b}$ inset). Modeling shows that the rays associated with the $6.0 \mathrm{~km} / \mathrm{s}$ velocity

367 travel through the layer beneath the deepest sedimentary horizon. Beyond this range another weaker

368 first arrival is discernible with a velocity of $8.0 \mathrm{~km} / \mathrm{s}$ typical of the upper mantle Pn. Based on the above

369 constraints, the depth to the top of the upper mantle is $\sim 14 \mathrm{~km}$ and the crustal thickness is $\sim 4 \mathrm{~km}$ or

370 possibly less because the coincident reflection profile shows basement relief of $\sim 1 \mathrm{~km}$.

371

372 Offshore of Alaskan margin is the region with the densest concentration of sonobuoys with velocities

373 typical of continental crust: SB 1001, SB 1003 (Fig. 6), SB 1005, SB 1006, SB 1007, and SB 0713, (Figs. 1

374 and 3). For example on SB1001 (Figs. 1 and 3a), a refraction of $4.9 \mathrm{~km} / \mathrm{s}$ is observed and interpreted to

375 be continental basement. Wide angle reflections beneath this layer indicate velocities in the range of

$3765.1-5.4 \mathrm{~km} / \mathrm{s}$ above the clear PmP. SB 0713 and SB 1003, respectively located about $300 \mathrm{~km}$ and $265 \mathrm{~km}$

377 north of the $2000 \mathrm{~m}$ contour have thinner sedimentary layers and stronger crustal events. Hence,

378 continental crust is interpreted to extend well into the deep-water portion of Canada Basin off this part

379 of Alaska. However, on sonobuoys nearest the margin due to the thick sedimentary section, many of the

380 crustal arrivals are weak and the sedimentary basement layer is obscured by the multiple.

382 In contrast, the area offshore of the Mackenzie Delta has only two sonobuoys (SB 1028 and SB 1030)

383 (Figs. 1 and 3a) that have been interpreted to have continental velocities. On SB 1028 refractions with

384 velocities of 5.5 and $6.6 \mathrm{~km} / \mathrm{s}$ are measured. On SB 1030 no crustal refractions are observed but wide

385 angle reflections from the crust exist together with a clear PmP. In order to match the curve of the

386 crustal reflections and PmP arrivals, a masked layer with a velocity of $6.2-6.4 \mathrm{~km} / \mathrm{s}$ is required for the

387 crust. This velocity is within the range of continental crustal velocities measured by Stephenson et al. 
388 (1994) on the southeastern Beaufort Sea continental margin. Therefore, this area of thinned continental

389 crust is constrained to be much closer to the coast than is the case further west offshore Alaska.

391 In the northern Canada Basin along the Canadian Arctic Islands, only two sonobuoys are classified as

392 continental, although the data coverage is sparse. SB 0928-1 (Figs. 1 and 3a) is located in a unique, high393 relief basement depression about $130 \mathrm{~km}$ across (Fig. 8), interpreted as a graben structure (Hutchinson

394 et al., 2012). This sonobuoy is in deep water $\sim 250 \mathrm{~km}$ seaward of the $2500 \mathrm{~m}$ contour, indicating thinned

395 continental crust here, similar to offshore Alaska, may extend significantly offshore. Offshore of

396 southern Prince Patrick Island, SB 1020 (Fig. 1) has a complex sedimentary section with low velocity

397 zones (Chian and Lebedeva-Ivanova, 2015). An arrival of $6.6 \mathrm{~km} / \mathrm{s}$ is consistent with the presence of thin 398 continental crust (Fig. 3c).

400 Two sonobuoys with continental crust are also seen near the northern end of Northwind Ridge. SB 0815

401 is in shallow water on the ridge has a $5.0 \mathrm{~km} / \mathrm{s}$ arrival and a poorly resolved $6.0 \mathrm{~km} / \mathrm{s}$ event. SB 0933-1

402 has several crustal velocities ranging from 4.4 to $6.6 \mathrm{~km} / \mathrm{s}$ and is located near its northern tip. These

403 sonobuoys velocities are consistent with the interpretation based on geological sampling that

404 Northwind Ridge is a continental fragment (Brumley et al., 2015).

405

406 Upper mantle refractions (Pn) are observed on SB 1003, SB 0713 and SB 0928 with continental affinities.

407 The Pn arrival on SB 1003 and the nearby SB 0713 constrains crustal thickness to 3-4 km and 6 km

408 respectively. The crustal thickness on SB 0928-1 located in the northern portion of Canada Basin

409 offshore of the Canadian Arctic Islands is $7 \mathrm{~km}$. Strong PmP reflections are observed on several of the

410 other continental sonobuoys (SB 1010, SB 1003, SB 1005, SB 1006, and SB 1007) and are indicative of a 
411 sharp boundary at the M oho (e.g. Stein and Wysession, 2003). W ith estimates of crustal thickness in the

412 range of $\sim 3-5 \mathrm{~km}$ and $M$ oho depths of $11-16 \mathrm{~km}$, this continental crust is therefore extremely thinned.

413

$414 \quad 4.2$ Integration with Potential Field Maps

415 The widely spaced sonobuoys and reflection profiles provide general constraints on the distribution of

416 oceanic, transitional and continental crust. Maps of magnetic and gravity anomalies (Fig. 7 and 8)

417 provide independent data types to further define the spatial distribution of the crustal types. The

418 oceanic polygon is then compared with the potential field data. The circum-Arctic magnetic anomaly

419 map (Gaina et al., 2014) shows that Canada Basin has muted magnetic anomalies compared with the

420 large amplitude magnetic anomalies associated with Alpha Ridge just to the north of it (Fig. 7, Saltus et

421 al., 2011). In the central Canada Basin, the region with linear conjugate magnetic anomalies (Fig. 7) has

422 been interpreted as evidence of seafloor spreading (e.g. Vogt et al., 1982; Grantz et al., 2011).

423

424 The Free air gravity map of Canada Basin (Fig. 8) derived from Andersen et al., (2010) is dominated by

425 large amplitude shelf-edge paired positive-negative gravity anomalies along the edges of Canada Basin

426 that range from 50-150 mGals (Stephenson et al., 1994). An important but smaller scale feature is the

427 narrow low amplitude negative gravity anomaly, the Canada Basin Gravity Low (CBGL), that stretches

428 from the M ackenzie Delta area to the northeast of Canada Basin (Fig. 8). The CBGL has two parts, a

429 southern segment that extends towards the Beaufort Sea, and a northern part, which bisects the

430 oceanic domain polygon, consistent with its earlier interpretation as the location of the fossil ridge axis

431 (Laxon and M cAdoo, 1994). The change in direction between the northern and southern segments of

432 the CBGL occurs about $150 \mathrm{~km}$ south of the edge of the oceanic domain. Although the geometry of the

433 northern segment of the CBGL can be associated with basement topography and an axial valley in the 
434 oceanic domain, neither our sonobuoy nor our reflection data are of sufficient resolution to determine

435 the character of the basement on the southern segment of the CBGL.

436

437 4.2.1 Oceanic Crust

438 Within the polygon that describes the $\mathrm{OCB}$, the velocity data indicate oceanic crust, sub-parallel linear

439 magnetic anomalies occur (Fig. 7), consistent with the hypothesis that oceanic magnetic anomalies are

440 formed by seafloor spreading (Vine and M atthews, 1963). These linear anomalies have been previously

441 interpreted as evidence of M esozoic seafloor spreading in Canada Basin (Taylor et al., 1981, Vogt et al.,

442 1982; Grantz et al. 2011). The character of the inner pair of aligned circular highs is similar to those

443 observed over oceanic crust in slow or ultra-slow spreading regimes (Dick et al., 2003, Brozena et al.

444 2003; Cannat et al., 2006). Visual inspection suggests that the linear magnetic anomalies (Fig. 7) could

445 extend south of the limit of oceanic crustal mapped by velocities. SB 0713 is strategically located for

446 constraining this boundary. The $6.6 \mathrm{~km} / \mathrm{s}$ velocity that is critical for identifying continental crust is a

447 weak arrival on the sonobuoy record and, combined with our estimated error of $\pm 0.2 \mathrm{~km} / \mathrm{s}$, suggest the

448 possibility that it could be interpreted as oceanic crust of a velocity of $6.8 \mathrm{~km} / \mathrm{s}$. It is also possible that

449 the high-amplitude magnetic anomalies characterizing the onshore-offshore magnetic D3 domain of

450 Arctic Alaska (Saltus et al., 2011) that is postulated to have thicker and probably stronger lower crust are

451 merging with the oceanic magnetic anomalies and making it difficult to separate the two regions.

452

453 The paired conjugate magnetic anomalies fan slightly northward until they reach about $77^{\circ} \mathrm{N}$. Northward

454 on the eastern (Canadian Arctic Islands) side of the basin the outer paired anomaly changes direction

455 and the amplitude decreases. The outer magnetic anomaly trends northwesterly and the oceanic crustal

456 domain narrows, consistent with the sonobuoy velocity data (Fig. 7). Northward of the paired oceanic

457 anomalies on the western side of the basin the outer paired magnetic anomaly approaches Northwind 
458 Ridge at an angle. The high amplitude Northwind Ridge M agnetic Anomaly (NoRM A) becomes the

459 dominant magnetic feature. The velocity data are complex in this region near the northern end of

460 Northwind Ridge. There are about 10 sonobuoys displaying the variations: for example on SB 0901-2 a

$4616.6-6.8 \mathrm{~km} / \mathrm{s}$ velocity overlies a $7.4 \mathrm{~km} / \mathrm{s}$, on SB 0901-3 a $6.4-6.5 \mathrm{~km} / \mathrm{s}$ velocity overlies a $7.3 \mathrm{~km} / \mathrm{s}$ layer,

462 and on SB 0901-4 a 6.7-6.8 km/s layer overlies a 7.3km/s event. Oceanic crust, underplating and/or

463 intrusion of magmatic material due to the proximity of the HALIP (Maher, 2001; Døssing et al., 2013) are

464 possible causes of the two lower crustal velocities.

465

$466 \quad$ 4.2.2 Transitional Crust

467 Lundin and Doré (2011) have pointed out the difficulty of assigning velocities in the range of 7.1 -7.7

$468 \mathrm{~km} / \mathrm{s}$ to particular rock types and that geological setting is important in assessing their origin.

469 Transitional crust in southern Canada Basin is associated with lower amplitude amorphous magnetic

470 anomalies of variable size and orientation. Some of this pattern may be the result of the great thickness

471 of sedimentary section beneath the Mackenzie fan, depressing both the basement and magnetic source

472 layers, but this pattern could also result from demagnetization of the crust similar to anomalies resulting

473 from serpentinization (Whitmarsh et al., 1993; Bronner et al., 2011). The general similarity of these

474 anomalies with the adjacent continent, particularly the Canadian Arctic Islands (Fig. 7), suggests that at

475 least some of this transitional crust is associated with the rifting processes that preceded formation of

476 oceanic crust in Canada Basin. By analogy with Iberia (Whitmarsh et al., 2001), we favor the

477 interpretation that this area of transitional crust is serpentinized mantle underlying extremely thinned

478 continental crust.

479

480 In contrast, an elongate high-amplitude magnetic anomaly (NoRM A) dominates the transitional crust

481 subparallel to and just east of Northwind Ridge in the western and northwestern Canada Basin. This 
482 intense anomaly is considered part of Alpha Ridge magmatic zone (Saltus et al., 2011), the 7.3-7.7 km/s

483 velocities may be due to the emplacement of magmatic material related to Alpha Ridge (Døssing et al., 484 2013). The actual velocity measured on 4 sonobuoys (SB 0812, SB 0813, SB 0901-3, and SB 1016) near

485 the northern tip of Northwind Ridge is $7.3 \mathrm{~km} / \mathrm{s}$ and on SB 1017 a velocity of between 7.2 and $7.4 \mathrm{~km} / \mathrm{s}$

486 is noted. P-wave velocities of $7.3 \mathrm{~km} / \mathrm{s}$ are unique to this region and their implications are discussed in 487 section 5.5 .

489 4.2.3 Thinned Continental Crust

490 The area of thinned continental crust in southern Canada Basin, near Alaskan margin, is another region

491 where the magnetic data are helpful in refining crustal type. Saltus et al. (2011) defined a broad positive

492 magnetic anomaly D3 in Alaska that could extend offshore (Fig. 7) and roughly encompass the area of

493 thinned continental crust, as defined by lower crustal velocities $\leq 6.6 \mathrm{~km} / \mathrm{s}$. The offshore portion of the

494 D3 domain may be a structurally competent continental crustal block that resisted breaking apart during 495 the rifting process.

$497 \quad 4.3$ Seismic Transects

498 Coincident seismic reflection profiles provide the opportunity to compare the reflection characteristics 499 with crustal types inferred from sonobuoy velocity classifications and potential field data to better 500 understand the tectonic setting of Canada Basin. Here we use depth to basement, basement topography 501 and reflectivity to further refine our interpretations of crustal domains. Four transects (Figs. 9-12) in 502 Canada Basin (Figs. 1, 7, 8) illustrate oceanic crust and the adjacent crustal domains.

503

504 4.3.1 North Canada Basin Transect (Fig. 9) 
505 The composite profile across north Canada Basin (Fig. 9) reaches from near the northern tip of

506 Northwind Ridge to the adjacent margin offshore of northern Prince Patrick Island (Figs. 1, 7, 8). The

507 sedimentary section is generally less than $4 \mathrm{~km}$ thick along this transect. Oceanic crust that meets our

508 simple velocity criteria is at its narrowest width, about $150 \mathrm{~km}$, and mostly consists of a deep valley and

509 the adjacent basement highs. The shape of the valley is well defined, similar to the valley on slow- and

510 ultra-slow spreading mid-ocean ridge segments (Dick et al., 2003; Ehlers and Jokat, 2009). Its position

511 coincides with the position of the CBGL, adding an important detail in support of the interpretation that

512 the CBGL represents a fossil spreading center (Laxon and M CAdoo, 1994). The sedimentary deposits in

513 the valley are at least $1 \mathrm{~km}$ thicker than the surrounding deposits. Our interpretation of the seismic

514 section is that this is a fossil spreading center with axial valley and rift shoulders.

516 The top of transitional crust at the western boundary of the oceanic domain is $\sim 1 \mathrm{~km}$ deeper than the

517 rift shoulder and is highly reflective. The bright reflection (Fig. 9b inset) package (Fig. 9b and c) is offset

518 by as much as $0.5 \mathrm{sec}$ in many places, as if faulted, as it rises towards Northwind Ridge. Velocities within

519 this highly reflective unit (4.4-5.6 km/s) are consistent with the presence of basaltic flows, in which the

520 offsets are either due to faulting or they were emplaced on a faulted surface. Seaward dipping

521 reflections (SDRs) are also observed. On SB 1017 on the reflection line that obliquely crosses this

522 transect, a $6.2 \mathrm{~km} / \mathrm{s}$ is underlain by a $7.2 \mathrm{~km} / \mathrm{s}$ velocity that indicates transitional crust. However on SB

523 0901-4, just to the north of the seismic transect, a velocity $6.8-7.0 \mathrm{~km} / \mathrm{s}$ typical of layer 3 is observed on

524 the OCB. Lower crust velocities of 7.2-7.4 km/s are also observed, which is the basis for interpreting this

525 crust as transitional crust. However this region could be oceanic crust with additional high velocity

526 magmatic material from the adjacent Alpha Ridge. Near where the transect crosses Northwind Ridge,

527 weathered basalts interpreted to originate from basalt flows and shallow water volcaniclastic deposits

528 were dredged in 2008 and 2009 (Mukasa et al., 2009; Brumley et al., 2015). Near and on Northwind 
529 Ridge, velocities of 6.3-6.4 km/s, are interpreted to be continental crustal velocities, which is consistent

530 with Northwind Ridge (as part of the larger Chukchi Borderland) representing a subsided crustal block.

531

532 On the eastern side of the transect, a thicker sedimentary section with associated deeper basement

533 (location at SB 0928-1) and irregular depths to basement with abrupt offsets is imaged (Fig. 9b). There is

534 only one seismic profile that crosses this depression but its extent can be traced along a rectangular-

535 shaped negative gravity anomaly approximately $60 \mathrm{~km}$ across and $200 \mathrm{~km}$ long (Fig. 8). The sub-

536 sedimentary velocity of $6.2 \mathrm{~km} / \mathrm{s}$ is interpreted as continental. The edges of this deep basin on the

537 gravity map have a northeasterly trend and could be wrench-related if the offsets are interpreted as

538 faults on basement. If the offset bright reflections are related to flows or sill intrusions rather than

539 faulting, the basin may alternatively be a deeply subsided pre-rift basin. The magnetic map (Fig. 7)

540 shows a narrow linear magnetic anomaly in this deep basin, the anomaly is about $20 \mathrm{~km}$ across and 80

$541 \mathrm{~km}$ long. At the eastern edge of the profile a prominent basement high associated with an ovoid

542 positive magnetic anomaly (Fig. 7) may be a volcanic edifice. If the basement depth were due to

543 extensive stretching and subsequent capping with flows or intrusives, it might compensate for the

544 narrowing of the oceanic crust at the axial valley on this transect.

545

546 4.3.2 Central Canada Basin Transect (Fig. 10)

547 The composite profile across the central part of Canada Basin (Figs. 1, 7, 8) is in a region where

548 sedimentary units are between 4 and $7 \mathrm{~km}$ thick. The oceanic crust is about $340 \mathrm{~km}$ in width here. The

549 profile illustrates both symmetric and asymmetric features. The symmetry is illustrated by the distinctive

550 low-amplitude, high-relief basement reflection associated with oceanic crust surrounded by high-

551 amplitude, low-relief reflections in the adjacent zones of transitional crust. The asymmetry is related to 
552 the shallower depth to base of the sedimentary section on the west near Northwind Ridge in contrast to

553 the east, where a greater sedimentary thickness has presumably depressed basement.

554

555 Oceanic crust is characterized by blocky relief with offsets between $0.5-2.0 \mathrm{~km}$. There is little

556 reflectivity below the basement horizon. The position of the CBGL is shown and is associated with a

557 depression in the basement relief at the position of SB 0810. The distribution of oceanic crust is

558 asymmetric about $200 \mathrm{~km}$ wide in the eastern portion and $140 \mathrm{~km}$ wide in the western section. On the

559 western side of the basin near Northwind Ridge, a lower crustal velocity of $7.4 \mathrm{~km} / \mathrm{s}$ (i.e., transitional

560 crustal velocities) is observed.

561

562 The base of the sedimentary layer on top of transitional crust (Fig. 10) on either side of the oceanic

563 domain has lower relief and in the west stronger reflectivity for about $0.5 \mathrm{~km}$ into the crust. Transitional

564 crust next to oceanic crust is also slightly deeper than the central oceanic basement blocks. Transitional

565 crust at the western end of the profile consists of an upper part that is 5-8 km thick with velocities

566 similar to either continental or upper oceanic crust $(5.0-6.6 \mathrm{~km} / \mathrm{s})$ and a lower part that is $6-7 \mathrm{~km}$ thick

567 with a velocity of $7.4 \mathrm{~km} / \mathrm{s}$. On the west, the zone of the transitional crust overlaps with the high-

568 amplitude magnetic anomaly NoRM A (Fig. 7). The transitional velocities of $7.4 \mathrm{~km} / \mathrm{s}$ have been called

569 high velocity lower crust (HVLC) and associated with underplated magmatic material similar to what

570 would be found along a magma-rich (volcanic) continental margin for the following reasons:(a) the

571 continuity of this anomaly with the magnetic domain of the Alpha Ridge (Saltus et al., 2011), (b) the

572 proximity of dredged basalts on Northwind Ridge (Andronikov et al., 2008; M ukasa et al., 2009), and (c)

573 the local presence of oceanic layer 3 velocities up to $6.8 \mathrm{~km} / \mathrm{s}$ in the transitional region. 
575 On the eastern (Canadian) side of the profile, basement in the narrow transitional crust zone is obscured

576 by the water-bottom multiple; however, where imaged in the multichannel data at its seaward

577 (western) edge, basement relief is subdued and contains bright reflections, similar to the reflectivity

578 patterns of basement near Northwind Ridge. SB 1020 has a thick sedimentary section and an upper

579 crustal velocity of $5.0 \mathrm{~km} / \mathrm{s}$. The nearby refraction data of Berry and Barr (1971) (Fig. 1) support the

580 interpretation of continental crust near the margin. The magnetic anomaly at the eastern end of the

581 profile is subdued compared with the western end.

582

583 4.3.3 South Canada Basin Transect (Fig. 11)

584 The southern transect crosses Canada Basin $\sim 300 \mathrm{~km}$ south of the central transect (Figs. $1,7,8$ ), in a 585 location where the sedimentary section is several kilometers thicker (Fig. 11). Good reflection and

586 refraction control is limited to the region west of the CBGL with SB 1025 and SB 1024 constraining

587 velocities and depths in the thick sedimentary section along the Canadian polar continental margin.

588 Oceanic crust is $160 \mathrm{~km}$ wide on either side of the low amplitude CBGL. Basement deepens west of the

589 CBGL, but whether it is a valley cannot be easily determined because of the weak reflections at the

590 basement surface. As in the other transects, the top of oceanic crust is blocky and weakly reflective. The

591 oceanic basement surface is poorly imaged between the CBGL and the Canadian continental margin. At

592 6-7 km thick (SB 0725, SB 0726), crustal thicknesses are only slightly less than those of typical oceanic

593 crust.

594

595 Transitional crustal velocities on this transect are 7.4-7.6 km/s (SB 1013, SB 0723 and SB 0724). On the

596 western edge of the transect (Northwind Ridge), the top of transitional basement has bright reflections

597 (Fig. 11C). A small sub-basin located at SB 1013 could be a synrift structure. Beneath the sedimentary

598 layers, velocities of $4.5-5.2 \mathrm{~km} / \mathrm{s}$ are interpreted to be highly extended continental crust that is $4-5 \mathrm{~km}$ 
599 thick above the deep transitional $(7.4 \mathrm{~km} / \mathrm{s})$ body. This transitional layer is up to $5 \mathrm{~km}$ thick (SB 1013)

600 and $225 \mathrm{~km}$ wide. The existence of a separate M oho arrival and the location of this body adjacent to

601 Northwind Ridge suggest that this transitional crust is underplated magmatic material. Were it

602 serpentinized upper mantle, the $7.4 \mathrm{~km} / \mathrm{s}$ event would be the top of upper mantle, nor would one

603 expect strong, clear, separate arrivals for a PmP or Pn. Near SB 0723 and SB 0724, velocities in the upper

604 mantle are not well enough constrained to determine whether the transitional body actually thins

605 towards oceanic crust, although the top of the transitional body does deepen from $12 \mathrm{~km}$ at SB 1013 to

$606 \sim 14 \mathrm{~km}$ at SB 0724. A sonobuoy on the eastern, Canadian margin (SB 1024) yields sedimentary velocities

$607(4.8 \mathrm{~km} / \mathrm{s})$ to a depth of $14 \mathrm{~km}$ below the sea surface. The nearest offline SB 1025, approximately $90 \mathrm{~km}$

608 further south, shows a $7.4 \mathrm{~km} / \mathrm{s}$ event as a strong reverberation at $11-22 \mathrm{~km}$ offsets, but only a weak,

609 reverberatory first arrival at offsets of $22-45 \mathrm{~km}$ is recorded on SB 1025 . There is no indication of a

610 deeper Pn arrival. This transect indicates major differences in crustal thickness, refraction character,

611 and depth between the eastern and western zones of transitional crust. Our preferred interpretation is

612 that transitional crust on the eastern, Canadian margin is serpentinized peridotite.

613

614 4.3.4 North-South Canada Basin Transect (Fig. 12)

615 The final transect crosses the basin from the center of oceanic crust south to Alaskan margin (Fig. 12).

616 This transect is located west of the CBGL (Figs. 1, 7, 8). Oceanic crust in this transect is similar to its

617 character on the central and southern transects, and is a low-amplitude, high-relief reflection. Oceanic

618 layer 3 crustal velocities of $6.9-7.0 \mathrm{~km} / \mathrm{s}$ are first arrivals and well constrained in SB 0726, SB 0727, SB

619 0728. On SB 0804, a 6.6 km/s layer is determined on a weakly defined refraction (Chian and Lebedeva-

620 Ivanova, 2015). SB 0805 is projected into the transect to show sedimentary velocities, but is in the fossil

621 spreading center within the CBGL anomaly and has a transitional crust velocity $(7.4 \mathrm{~km} / \mathrm{s})$, similar to

622 other velocities measured in slow and ultra-slow spreading centers (Jokat et al., 2003; Jokat et al., 2012). 
624 A $50 \mathrm{~km}$ wide zone of transitional crust is adjacent to oceanic crust (SB 1004, Fig. 12), defined by a

625 strong $7.5 \mathrm{~km} / \mathrm{s}$ refraction. About $10 \mathrm{~km}$ to the northwest of SB 1004, SB 0715 has a transitional crustal

626 velocity of $7.4 \mathrm{~km} / \mathrm{s}$, confirming the presence of this narrow strip of transitional crust. This is the

627 narrowest transition zone measured in the basin.

628

629 Along Alaskan margin, sedimentary strata are up to $10 \mathrm{~km}$ thick and are constrained by the presence of

630 subhorizontal, subparallel reflections down to the first multiple reflection and by velocities (Fig. 12) that

631 are as much as $4.7-4.9 \mathrm{~km} / \mathrm{s}$ (SB 1007, SB 1006, and SB 1005). On the basis of observed crustal velocities

632 that are typical of continental crust (5.0- $6.4 \mathrm{~km} / \mathrm{s})$, crustal thicknesses less than $5 \mathrm{~km}$, and wide-angle

633 arrivals modelled with upper mantle velocities of 8.0 - $8.1 \mathrm{~km} / \mathrm{s}$ (i.e., precluding the presence of oceanic

634 or transitional velocities), this 180-km wide region is interpreted as thinned continental crust.

635

636 In summary, the reflection data add to the picture of the different crustal zones. The top of oceanic

637 crust is typically a weak reflection of high relief compared to the strongly reflective and lower relief at

638 the base of the sedimentary section in the transitional zone. A depression or valley is associated with

639 the CBGL, consistent with the interpretation that it represents a fossil spreading center (Laxon and

640 McAdoo, 1994) with a central rift valley, typical of slow-spreading to ultra-slow spreading ridges (Dick et

641 al., 2003, Jokat et al., 2003). In general, large blocks with offsets up to $2 \mathrm{~km}$ define the morphology of

642 oceanic crust, which is much better imaged west of the CBGL. The edges of the transitional crust, while

643 clear on the reflection seismic data where transitional and oceanic crust meet, are not well constrained

644 along the continental margins where transitional and extended continental crust meet. This is mostly

645 because of insufficient data coverage. 
647 Continental crust along the Alaskan and Canadian Beaufort margins is not often imaged in the seismic

648 reflection data because of interference from the water bottom multiple. Where velocities do not

649 indicate oceanic or transitional crust, continental crust is highly extended and often less than 5-10 km

650 thick. Sonobuoys at the north end of Northwind Ridge confirm its origin as a submerged continental

651 block. Another possible continental block is buried beneath the northeast Canada Basin (Fig. 9) where a

652 large graben structure exists.

653

\section{Discussion}

6555.1 Comparison with published long offset wide angle reflection/ refraction data

656 Several previous regional crustal refraction experiments in Canada Basin (Fig. 1) with offsets of up to

$657200 \mathrm{~km}$ (e.g. Mair and Lyons 1981) provide an important comparison with our more detailed but shorter

658 offset sonobuoy data, especially in determining the velocities and depths of the lower crust and mantle. 659

\subsubsection{Near Alaskan margin}

661 Near the central Alaskan margin in southern Canada Basin (Figs. 1 and 13), M air and Lyons (1981) used 662 sparsely spaced explosive shots on a cross array and recorded clear refractions. The primary velocities 663 measured were a $4.3 \mathrm{~km} / \mathrm{s}$ arrival, a weaker event of $6.6 \mathrm{~km} / \mathrm{s}$ with a low gradient and a better defined $664 \quad 7.5-7.7 \mathrm{~km} / \mathrm{s}$ layer with a high gradient increasing to $8.1-8.4 \mathrm{~km} / \mathrm{s}$ out to a range of $200 \mathrm{~km}$. Their 665 velocity model is projected onto our adjacent line in Figure 13 with sonobuoys measurements and 666 reflection profiles. Their velocities of $4.3-4.5 \mathrm{~km} / \mathrm{s}$ were interpreted as representing oceanic layer 2.

667 The 4.4-4.6 km/s velocities that we measure can be compared to our coincident reflection profiles 668 where a thick sedimentary section is observed. Without access to reflection profiles, they assumed that 669 these velocities represented oceanic layer 2. 
671 Beneath this layer they interpreted only a few first arrivals in the $20-40 \mathrm{~km}$ range to constrain the 6.6-

$6726.8 \mathrm{~km} / \mathrm{s}$ velocity. However, the geometry of their cross array shows this layer thickens towards the

673 margin and has a low gradient. On SB 1002 near the M air and Lyons experiment, we observed a 7.5

$674 \mathrm{~km} / \mathrm{s}$ refraction associated with a strong reflection that requires a continental velocity of $5.0 \mathrm{~km} / \mathrm{s}$ to

675 model its shape. On SB 1003, the basement refraction velocity of 5.9-6.0 km/s is typical of continental

676 crust and underlies the clear sedimentary section determined from the coincident seismic reflection

677 profile. On nearby SB 1005 (Fig. 12), beneath the sedimentary section, velocities of 4.9, 5.3 and 6.0

$678 \mathrm{~km} / \mathrm{s}$ are interpreted from a noisy record section. On SB 1006 (Fig. 12), velocities of 5.0-5.3 and 6.0-6.6

$679 \mathrm{~km} / \mathrm{s}$ are weak and accompanied by a strong PmP. M air and Lyons (1981) interpreted their 6.6-6.8 km/s

680 as oceanic. The lower velocities on the sonobuoys, the lack of linear magnetic anomalies and the surface

681 characteristics of basement suggest thinned continental crust.

682

683 Mair and Lyons (1981) measured a $7.6 \mathrm{~km} / \mathrm{s}$ velocity consistent with our observations of $7.5 \mathrm{~km} / \mathrm{s}$

684 velocities on SB 1002 and SB 1004. Furthermore, they were able to determine that this layer had a high

685 gradient based on their long offset arrivals. They interpreted this layer as either part of oceanic layer 3

686 or serpentinized peridotite. Oceanic layer 3 does not typically have a high gradient or velocities in the

687 range of 7.5-7.6 km/s but a serpentinized layer does (Christensen, 2004). Therefore in our model (Fig.

688 13) this layer is interpreted as serpentinized peridotite underlying thinned continental crust consistent

689 with the generalized model of a magma-poor margin (Fig. 2).

690

691 The sedimentary section (Fig. 13), as interpreted from the seismic reflection profile and the velocities,

692 thickens from SB 0726 towards the margin. The crustal layer thins from the continental margin towards

693 the centre of the basin where it is underlain by a 7.5-7.6 km/s layer. The transition to oceanic crust (Fig.

694 13) takes place, not at the shelf break (M air and Lyons, 1981), but $275 \mathrm{~km}$ seaward of the shelf break 
695 between SB 1003 and SB 0726. As illustrated on SB 0726, well defined layer 3 velocities of 6.9-7.1 km/s

696 and lineated magnetic anomalies are observed. The broad magnetic anomalies near SB 1006 (the D3

697 zone of Saltus et al., 2011) are gradually replaced by more linear anomalies that continue seaward in the

698 region displaying clear oceanic crustal velocities. The zone where magnetic lineations are observed, but

699 velocities suggest the presence of continental crust, occur at the ocean-continent boundary suggesting

700 that the continental crust has been intruded with basaltic rocks.

701

$702 \quad 5.1 .2$ Near southern Northwind Ridge

703 Also in southern Canada Basin, Baggeroer and Falconer (1982) carried out a crustal refraction program 704 near and parallel to SB 1009, SB 1010 and SB 1011 (Figs. 1 and 14). They used two types of receivers, a 705 multichannel hydrophone L-shaped array with $600 \mathrm{~m}$ length on each arm and an ocean bottom 706 seismometer. The sound source was 5 explosive charges at offsets from 39 to $73 \mathrm{~km}$. They recorded a 707 very strong event with an estimated velocity of $4.9 \mathrm{~km} / \mathrm{s}$ arrival and a $7.9 \mathrm{~km} / \mathrm{s}$ arrival that they 708 interpreted as the Moho. Their experiment was located only $5 \mathrm{~km}$ to the east of one of our reflection 709 profiles and about midway between SB 2009 and SB 2010. SB 1009 and SB 1010 recorded high 710 amplitude 4.5-4.6 km/s arrivals. On SB 1011, weaker but observed velocities of 5.0 and $5.8 \mathrm{~km} / \mathrm{s}$ are also 711 seen (Chian and Lebedeva-Ivanova, 2015), similar to the $4.9 \mathrm{~km} / \mathrm{s}$ velocity of Baggeroer and Falconer 712 (1982). A velocity of $7.5 \mathrm{~km} / \mathrm{s}$ is observed on the sonobuoy data breaking over as a first arrival at about $71325 \mathrm{~km}$ offset. Baggeroer and Falconer (1982) observed a velocity of $7.7 \mathrm{~km} / \mathrm{s}$ from 39.4 to $73.2 \mathrm{~km}$ range 714 with the $4.9 \mathrm{~km} / \mathrm{s}$ event breaking over to $7.9 \mathrm{~km} / \mathrm{s}$ event at $29.1 \mathrm{~km}$. The depth to the high velocity layer $715 \quad 7.5-7.7 \mathrm{~km} / \mathrm{s}$ is predicted to be $9.8-10.7 \mathrm{~km}$ below the seafloor by Baggeroer and Falconer (1982), 716 consistent with the velocity model for SB 1011. 
718 The results of both experiments are similar but difficulties in interpreting them remain. The $4.5 \mathrm{~km} / \mathrm{s}$

719 arrival on the sonobuoy data, when compared with the coincident reflection profile, occurs within the

720 sedimentary section. It is puzzling why a $4.5-4.9 \mathrm{~km} / \mathrm{s}$ sedimentary arrival at about $4.3 \mathrm{~km}$ depth within

721 a 6 km thick sedimentary section should be so strong a refraction. Baggeroer and Falconer (1982) made

722 an important observation that this event exhibits high attenuation with offset, suggesting a sharp

723 gradient typical of a change at the sedimentary basement interface. They also commented that their 4.9

$724 \mathrm{~km} / \mathrm{s}$ velocity was high for a sedimentary layer and could mean that this layer was compacted

725 sedimentary material. Baggeroer and Falconer (1982) were also concerned that no layer 3 velocities had

726 been measured. Based on spectral analysis of the array data, layer 3 was thin (less than 2 km thick) or

727 absent. The location of their experiment coincides with the region of thinned continental crust

728 extending north from Alaskan margin (SB 1001 to SB 1005). In our more spatially distributed and shot-

729 intensive sonobuoy data, velocity analysis did not reveal a typical layer 3 oceanic velocity. Our favored

730 interpretation is a thick sedimentary section overlying thin continental crust with a velocity of 5.0-5.8

$731 \mathrm{~km} / \mathrm{s}$, with a measured M oho velocity beneath it.

732

733 Moreover, when our velocities from SB 1009, SB 1010 and SB 1011 are plotted on the coincident

734 reflection profile, our $4.8 \mathrm{~km} / \mathrm{s}$ arrival on SB 1009 and SB 1010 corresponds with a major change in the

735 reflection profile to lower frequency, less parallel arrivals suggesting the top of basement. The velocity

736 of the crust ranges from $4.8-5.3 \mathrm{~km} / \mathrm{s}$ consistent with continental velocities with no indication of oceanic

737 layer 3. Near SB 1011 the possible basement horizon changes character (Fig. 14). A series of high

738 amplitude, probably sedimentary, reflections are observed infilling an irregular basement structure. The

739 velocity function for SB 1011 is typical of transitional crust with a $7.5 \mathrm{~km} / \mathrm{s}$ measurement. Similar

740 topographic irregularities in base of the sedimentary layer and the change to serpentinized crust also 
741 occur on the North-South transect (Fig. 12). The magnetic map (Fig. 7) shows a strong positive anomaly

742 in the vicinity of SB 1009 and SB 1010 (Fig. 1) becoming subdued at the location of SB 1011.

$744 \quad$ 5.1.3 Near the Canadian polar margin

745 Along the northern Canadian margin (Figs. 1 and 10), Berry and Barr (1971) conducted a refraction 746 experiment that had sparse recording and shot intervals. They measured a crustal velocity of $5.4 \mathrm{~km} / \mathrm{s}$

747 and a M oho velocity of $8.1 \mathrm{~km} / \mathrm{s}$ at a poorly resolved depth of $15 \pm 9 \mathrm{~km}$ mid-way down the continental 748 slope, suggesting thinned continental crust. Two sonobuoys near to, but seaward of the Berry and Barr 749 (1971) refraction line (Fig. 1) provide additional data for the crust in deeper water. SB 1020, slightly 750 south and seaward of the Berry and Barr (1971) line has a well resolved $6.6 \mathrm{~km} / \mathrm{s}$ layer. The sonobuoy

751 closest to the continental margin, SB 0834, (Fig. 9) recorded data sporadically beyond 17 km offset;

752 however, there were indications of refraction with a $7.4 \mathrm{~km} / \mathrm{s}$ velocity typical for transitional crust. 753

754 In summary, the earlier refraction experiments in the Canada basement can be put in context with our 755 results. M ost of these experiments were along the edges of Canada Basin and did not have coincident 756 reflection profiles making it difficult for the extent of the thick sedimentary deposits to be resolved. The 757 high velocities in the range of $4.5-4.9 \mathrm{~km} / \mathrm{s}$ in sedimentary section were often interpreted as oceanic 758 layer 2. None of the earlier experiments identified a clear oceanic layer 3 velocity. Based on their 759 distribution in the periphery of Canada Basin, none of them were actually located on oceanic crust. Our 760 more closely sampled sedimentary and upper crustal wide angle reflection/refractions, the magnetic 761 patterns and reflection profiles suggest these experiments actually recorded a sedimentary section 762 overlying transitional or thinned continental crust, consistent with their lack of oceanic velocities. 763

\section{$764 \quad 5.2$ Constraints on the Opening of Canada Basin}


765 The sonobuoy velocities, seismic reflection profiles and potential field data consistently describe a

766 region of typical and distinctive oceanic crust in Canada Basin (Fig. 15), primarily associated with the

767 northern segment of the CBGL. Our data distribution is insufficient to assign crustal type near and to the

768 west of the southern segment of the CBGL. The paired magnetic anomalies and the general symmetry of

769 oceanic crust around the CBGL, are consistent with the counter clockwise rotation of Alaska with a pole

770 of rotation located in the south of the Beaufort Sea (e.g., Grantz et al., 2011, and included references).

771

772 The combined data sets indicate that the area of oceanic crust is a sub-region of the larger Canada Basin

773 (Fig. 15) and a plate reconstruction must also account for the unknown but finite extension in the

774 transitional crust (e.g., Alvey et al., 2008; M üller et al., 2008). The added space from this more

775 restricted closure might accommodate parts of Northwind Ridge and the Chukchi Borderland, which

776 otherwise require special tectonic accommodation to avoid the overlap with the Canadian Arctic Islands

777 (e.g., Grantz et al., 2011; Brumley et al., 2015). Detrital zircon analysis identify that the Alaska Beaufort

778 margin was in close proximity with the opposing margin of the Canadian Arctic Islands during the

779 Ellesmerian Orogeny into M esozoic time (Gottlieb et al., 2014). The closure proposed in Gottlieb et al.

780 (2014) results in a $55^{\circ}$ rotation, or $10^{\circ}$ less than the $66^{\circ}$ rotation proposed by Grantz et al. (2011). The

781 width of the southern edge of the polygon of oceanic crust ( $340 \mathrm{~km}$ wide), puts limits on the amount of

782 rotation, assuming that the rotation is symmetrical around a pole south of the Beaufort Sea. However,

783 the new data presented here and onshore constraints (Lane et al., 2015) indicate that the rotational

784 model does not satisfy all the observations.

785

$786 \quad 5.3$ Rate and Age of Seafloor Spreading

787 The thickness and morphology of oceanic crust can augment magnetic anomalies in determining the

788 spreading rate of an ocean basin. Oceanic crustal thicknesses of 4 to $7 \mathrm{~km}$ in Canada Basin are typical of 
789 slow- spreading rates, i.e., less than full spreading rates of $20 \mathrm{~mm} /$ a that produce $6 \mathrm{~km}$ thick oceanic

790 crust at average mantle temperatures (Reid and Jackson, 1981; Bown and White, 1994). Faster

791 spreading rates produce average thicknesses of $7.1 \mathrm{~km}$ (White et al., 1992).

792

793 The morphology of the axial graben also helps constrain spreading rate (M acDonald, 1982) because

794 slower spreading rates are associated with deeper axial grabens. The depth of the axial graben in

795 Canada Basin based on the seismic reflection data (Fig. 9), is $\sim 1.5 \mathrm{~km}$, consistent with 1.5-3 km depths

796 typical of axial grabens formed by spreading rates of $10-20 \mathrm{~mm} / \mathrm{a}$. This depth is greater than the

797 estimate of Grantz et al. (2011), which was based on a single partial crossing of the axial graben. High

798 relief and roughness of the basement surface observed in the multichannel data is also consistent with

799 expected roughness from slow and ultraslow spreading ridges (M alinverno, 1991; Ehlers and Jokat

800 2009).

801

802 Regional geology can help constrain the time of rifting and extension and therefore also places limits on

803 the age of opening. Based on onshore geological constraints such as the dating of onshore rocks

804 assigned to the HALIP, the breakup unconformity, offshore heat flow data and paleomagnetic data on

805 the rotation, seafloor spreading in Canada Basin was estimated to have initiated in the Hauterivian

806 ( 134 M a, Embry and Osadetz, 1988; Embry and Dixon, 1994; Estrada, 2015) and slightly younger

807 offshore of Alaska (Hubbard et al., 1987). The width of the oceanic crust at its southern limit is about

$808320 \mathrm{~km}$ from the outside of the paired magnetic anomalies. The outer magnetic anomaly is more

809 continuous than the inner that is formed by a series of small circular highs. This could be due to the

810 magma generation processes slowing down as the spreading center became extinct. Our sonobuoy

811 velocities indicate the crust near the axial valley does not have all the crustal layers observed elsewhere.

812 A slow spreading rate of $20 \mathrm{~mm} /$ a would require about $15 \mathrm{M}$ a to produce this extent of crust. An 
813 ultraslow rate of less than $20 \mathrm{~mm} / \mathrm{a}$ is not consistent with the development of layer 3 velocities (Jokat et

814 al., 2012).

815

816 To correlate the seafloor magnetic anomalies in Canada Basin with the magnetic reversal sequence two

817 linear positive magnetic anomalies with an intervening negative anomaly (Fig. 7) are identified. This

818 reversal sequence cannot happen between $\sim 124$ and $\sim 33 \mathrm{M}$ a due to the long Cretaceous positive

819 polarity chron. Likewise, prior to M5 ( 130 M a), the many short reversals are unlikely to be preserved in

820 a slow spreading ocean basin. Both positive and negative reversals occur in the intervening time interval

821 of $\sim 130$ to $124 \mathrm{Ma}$ (i.e., between M 5 and M 0). This age is consistent with the Early Cretaceous age of

822 opening based on geological considerations (e.g., Embry and Dixon, 1994).

823

824 In order to fit the width of the negative anomaly (i.e. the trough between the two positives) with an 825 assumed spreading rate of $20 \mathrm{~mm} / \mathrm{a}, 5 \mathrm{M}$ a of time is required. However, the longest negative anomaly

826 duration between M 5 and M 0 is M 3, about 2.3 M a which would require a higher spreading rate of $\sim 35$

$827 \mathrm{~mm} / \mathrm{a}$ to fit the anomaly. This leaves us with an unresolved problem, that a higher spreading rate (e.g.,

828 of $35 \mathrm{~mm} / \mathrm{a}$ ) is required to create the width of the oceanic crust or the time frame is incorrect. If the

829 spreading rate is high, the thickness of oceanic crust should be consistently greater than the observed 4-

$8307 \mathrm{~km}$. A similar identification of magnetic chrons of M 4n to M 2n (130-127.5 Ma) has been suggested by

831 Grantz et al. (2011). This even more limited age range requires a spreading rate of $75 \mathrm{~mm} / \mathrm{a}$ that is also

832 inconsistent with anomalously thin oceanic crust measured from sonobuoy velocities. Another

833 possibility is that the paired magnetic anomies are younger. A single whole rock sample from Alpha

834 Ridge was dated using $\mathrm{Ar}^{40} / \mathrm{Ar}^{39}$ incremental heating with a plateau age of $89 \pm 1 \mathrm{Ma}$ (Jokat et al., 2013).

835 The reversal sequence at the end of the long positive chron C34 would be a better fit for a slow

836 spreading ocean. A third possibility is that the magnetic anomalies are due to basement topography. 
$838 \quad 5.4$ Seafloor Spreading

839 The sonobuoy velocity data do not uniquely constrain whether seafloor spreading preceded, coincided

840 with, or followed the magmatism associated with the HALIP. The inferred age of Canada Basin spreading

841 between 130- 124 M a closely coincides with onset of magmatism in the HALIP, $130 \mathrm{Ma}$ (M aher, 2001),

842 and revised duration of magmatism in the HALIP of 138-125 M a (Døssing et al., 2013) or possibly 130 -

$843101 \mathrm{Ma}$ (Evenchick et al., 2015). The sparse dates available from onshore dykes that radiate from Alpha

844 Ridge, the offshore segment of the HALIP, suggest basaltic magmatism starting at about $124 \mathrm{Ma}$

845 (Bleeker et al., 2012; Corfu et al., 2013). The age of bedrock sample from Alpha Ridge 89 \pm 1 Ma (Jokat et

846 al., 2013) suggests magmatism on the Alpha Ridge may have had a broad time span. The earliest dates

847 suggest that the creation of oceanic crust in Canada Basin for the region encompassing the northern

848 segment of the CBGL was coeval with initial formation of Alpha Ridge. This timing is probably also the

849 same as formation of the volcanic continental margin at the junction of Alpha Ridge with the Canadian

850 Arctic Islands margin (Funck et al., 2011).

851

852 The age of opening of southern Canada Basin, along the southern segment of the CBGL where it projects

853 ashore near the Mackenzie Delta (Fig. 15), is not well constrained. Transitional crust has not been

854 sampled or dated and is buried by up to $12 \mathrm{~km}$ of sedimentary strata beneath the Mackenzie Delta/Fan

855 depositional system (Shimeld et al., 2016). Southern Canada Basin has several characteristics that

856 distinguish it as a separate crustal entity: the more subdued magnetic character, the different

857 orientation of the CBGL relative to the region of oceanic crust further north, the consistently higher

858 sedimentary velocities (Shimeld et al., 2016) and the inferred existence of the oldest sedimentary units

859 along the Beaufort margins (e.g., Hutchinson et al., 2012; M osher et al., 2013). Extensional basins may

860 have begun forming as early as the Early Jurassic (Hubbard et al., 1987; Embry, 1991; Grantz et al., 1994; 
861 Harrison and Brent, 2005). Whether the transitional crust along the southern segment of the CBGL

862 represents an early (i.e., Jurassic or Early Cretaceous) opening or extension, or is coeval with the 863 formation of oceanic crust requires additional study and modeling.

864

$865 \quad 5.5$ The nature of the ocean-continent transition

866 The border drawn around the ocean crust polygon (Figs. 7, 8, and 15) defines the ocean-continent

867 boundary $(\mathrm{OCB})$, i.e., the location where the seaward edge of transitional crust and the landward edge

868 of oceanic crust meet. The OCB is the most controlled crustal boundary based on our data. It

869 corresponds to the edge of the ocean crust based on the velocity classification (Fig. 3), the edge of the

870 paired linear magnetic anomalies (Fig. 7), and the transition from irregular basement highs on oceanic

871 crust to smoother and, on the eastern, Canadian side, deeper basement on transitional crust on the

872 seismic reflection records (Figs. 9-13).

873

874 Outside of the OCB, the seismic data distribution is more widely spaced leading to more uncertainty in

875 characterizing the heterogeneous nature of the ocean continent transition (OCT), i.e., the zone where

876 rapid changes in crustal thickness, lithology, and deformation associated with rifting occurs (Fig. 15). The

877 landward extent of the OCT can be inferred from the integration of the seismic velocity, reflection

878 character, seafloor morphology and potential field anomalies (solid and dashed lines in Fig. 15), but is

879 largely unconstrained from lack of data under the thicker sedimentary cover at the intersection of the

880 Chukchi Borderland with Alaskan margin and along the Canadian Beaufort margins (question marks in

881 Fig. 15a). Nor have we attempted to map transitional crust towards the HALIP as it was mapped by

882 Saltus et al. (2011, white dashed line, Fig. 15). Because of the short hydrophone array necessitated for

883 towing in ice, ice conditions that prevented reaching some parts of the margins, and limits in data

884 collection to water depths generally deeper than $2000 \mathrm{~m}$ for cruise objectives, our data are not 
885 positioned to give full crustal transects from continental to oceanic crust. Nor are data sufficient to

886 subdivide the OCT into proximal, distal, necking, coupled, exhumed, or inner and outer zones as defined 887 by other authors (e.g., Peron-Pinvidic et al., 2013; Karner et al., 2012; Sutra and Manatschal, 2012).

889 The lower crustal velocities used to define the OCT show trends around the OCB. The OCT around the 890 northern extent of oceanic crust has velocities of 7.2-7.3 km/s (described in section 4.2.2). The OCT

891 around the southern extent of oceanic crust has consistently slightly higher velocities of 7.4-7.5 km/s.

892 The only sonobuoy record in southern Canada Basin with a velocity of $7.3 \mathrm{~km} / \mathrm{s}$ (SB 0709) is very noisy

893 with the direct arrival extrapolated from a weakly constrained wide angle reflection, rather than being

894 based on an observable refraction. The remaining 25 velocity classifications of transitional crust are 895 uniformly 7.4-7.5 km/s. Although these differences are near the limits of resolution of the refraction 896 measurements, their consistency across a large data set suggests the trend of slightly lower velocities in 897 the north and slightly higher velocities in the south is real.

899 There are good geological explanations for the velocity trends. The 7.2-7.3 km/s slightly lower velocities 900 are consistent with expected velocities from gabbroic melts (e.g. Lundin and Dore, 2011) and highly 901 intruded continental crust such as found off Norway (M jelde et al., 2005), Hatton-Rockall (Funck et al., 902 2008), the Canadian volcanic margin at Alpha Ridge (Funck et al., 2011), and southeastern Brazil (Evain 903 et al., 2015). The OCT around the northern extent of oceanic crust is likely to be a magma-rich OCT that 904 is dominated by magmatic intrusion and/or underplating in the lower crust.

906 The higher velocities of 7.4-7.5 km/s are consistent with velocities interpreted to be serpentinized 907 mantle measured and sampled off the southern Iberia (Whitmarsh et al., 1993; Chian et al., 1999; Dean 908 et al., 2000; Clark et al., 2007). Exhumed and serpentinized continental mantle is one of the dominant 
909 characteristics of magma-poor rifting and continental breakup such as documented off Iberia

910 (Whitmarsh et al., 2001; Lavier and M anatschal, 2006; Reston, 2009; Lundin and Dore, 2011). The OCT in

911 this southern area is likely to be representative of a magma-poor OCT that is dominated by

912 serpentinization of exhumed continental mantle.

913

914 A few seismic refraction and reflection criteria exist to help resolve between magma-rich and magma

915 poor settings, and our seismic data locally contain additional information. In a magma-poor setting, one

916 would expect a weak to non-existent M oho arrival because of the gradual change from serpentinized to

917 normal mantle over some depth range (e.g., Chian et al., 1999). In magma-rich setting, the M oho is

918 often a strong and distinct arrival (e.g., White et al., 2008). The offsets used in Canada Basin sonobuoy

919 data are not generally large enough to get robust Pn (M oho) arrivals, but one strong Pn arrival off the

920 Chukchi Borderland (SB 1013, star in Fig. 15) which yields a crustal thickness of $5 \mathrm{~km}$ is another

921 supportive piece of evidence that the OCT in that region is magma-rich. This thickness is within the

922 range that might be expected with underplated or intruded magmatic material (Blaich et al., 2011). This

923 Pn measurement and its association with a positive magnetic anomaly that appears to be continuous

924 with Alpha Ridge magnetic domain of Saltus et al. (2011, Fig. 15b) supports the origin of this crust to be 925 a mafic-rich, or underplated/intruded body.

926

927 The crust above the high-velocity lower crust in magma-rich continental margins can have a complex 928 distribution of basalt flows (seaward dipping reflections), sedimentary strata, and variable velocities as 929 well as variable thicknesses along transects (Peron-Pinvidic et al., 2013; Blaich et al., 2011 and

930 references therein). In our Canada Basin data, there are weak seaward dipping reflections in the north

931 (SDR in Fig. 9b), consistent with the magma-rich tectonic setting. Unfortunately, in the eastern and

932 southern (Beaufort) regions, the top of basement is often not imaged by the reflection data because of 
933 interference from the water-bottom multiple. Hence the evidence for possible magma-rich features

934 such as seaward dipping reflections in these regions is obscured. Similarly, the small airgun source, the 935 short streamer offsets, and the resulting strong water-bottom multiple also prevent imaging of a

936 possible mid-crustal detachment surface that is often characteristic of magma-poor continental margins 937 (Reston, 2009).

938

939 Moho is also inferred in our dataset from PmP (or reflections from M oho) or occasionally Pn (mantle 940 refractions), in approximately one quarter of the sonobuoys in the OCT. These PmP reflections have

941 strong or intermittent reverberatory arrivals suggesting a relatively sharp, rather than gradational,

942 interface at the top of upper mantle. PmP arrivals are often strong second arrivals at offsets less than 30

$943 \mathrm{~km}$ and are therefore not affected by degraded signal to noise at more distant offsets. In Canada Basin

944 sonobuoys, the PmP arrivals are distributed around the north, west, and south of oceanic crust. Their

945 distribution about the zone of oceanic crust, similar to the sonobuoys that lack PmP arrivals, suggests

946 that the upper mantle M oho is heterogeneous at the scale of this seismic experiment. This observation

947 does not necessarily eliminate serpentinized upper mantle as an interpretation because the actual

948 velocity measurements of 7.4-7.5 km/s are still diagnostic. However, the number and distribution of

949 PmP arrivals suggest more complexity than the simple gradational velocity model provides. Lacking

950 shear waves, our sonobuoy data cannot be used to calculate Vp/Vs ratios that could perhaps resolve

951 differences between intruded crust and serpentinized mantle (M jelde et al., 2002).

952

953 A final indicator of the heterogeneous nature of the OCT is its variable width (Fig. 15), which ranges from

$95420 \mathrm{~km}$ or less immediately north of Alaska to $\sim 250 \mathrm{~km}$ in the vicinity of the Mackenzie delta/fan. The

955 width is $\sim 200 \mathrm{~km}$ along the central Chuckchi Borderland and tapers northward towards the HALIP to less

956 than $100 \mathrm{~km}$. It is well known the widths of the OCT on conjugate margins of the North and South 
957 Atlantic are asymmetric and variable, and can be narrower than $\sim 50 \mathrm{~km}$ or wider than $\sim 200 \mathrm{~km}$ (Peron-

958 Pinvidic et al., 2013; Blaich et al., 2011 and references therein). The widths measured around Canada

959 Basin are therefore consistent with measurements and models from other passive margins.

960

961 Two blocks of crust interpreted to have continental crustal velocities abut the two narrowest zones of

962 the OCT, one in the south (Fig. 15; labelled and discussed earlier to coincide with the D3 magnetic

963 domain of Saltus et al., 2011) and one in the north (labelled 78 N, Fig. 15a). Narrow OCTs are often

964 associated with transform margins (Scrutton, 1979), but such an association is not compelling for these

965 regions in Canada Basin. Transform faults are not well developed at ultra-slow spreading ridges such as

966 the Knipovich or Gakkel Ridges in the Arctic) and the magnetic data in Canada Basin do not show offsets

967 that could be interpreted as transforms, either at the locations of these narrow OCTs or elsewhere (Fig.

968 15c). The basement depression at $78^{\circ} \mathrm{N}$ (Fig. 15) is a steep-sided sedimentary filled basement deep (Fig.

969 9) $80 \mathrm{~km}$ by $200 \mathrm{~km}$ in extent that is observed in the seismic and potential field data. More detailed

970 investigations to determine the extensional or strike/ slip origin would provide important constraints in

971 understanding the development of Canada Basin.

972

\section{Conclusions}

974 The most significant result, of the velocity analyses of the broadly geographically distributed sonobuoy

975 data, is that only the central part of Canada Basin is underlain by velocities typical of oceanic crust.

976 When the results of the assignments of velocities to crustal type are superimposed on the magnetic

977 map, we see only the regions with oceanic layer 3 velocities have linear anomalies typical of seafloor

978 spreading. In addition, the CBGL that has been previously attributed to the fossil spreading center

979 bisects the region identified as oceanic crust. Examination of the coincident seismic reflection profiles 
shows a deep sediment filled valley that is located along the northern segment of the CBGL. The seismic

981 reflection profiles with coincident oceanic crustal velocities show that the top of seismic basement has

982 high-relief crust and low reflectivity. Velocities determined to be typical of transitional crust are

983 observed on the periphery of the oceanic crust. On the reflection profiles the top of the transitional

984 crust has strong reflectivity and little relief. The magnetic data in the transitional crustal zone have

985 amorphous shaped anomalies. The junction of the oceanic and transitional crust, based primarily on 986 seismic refraction velocities and magnetic character supported by the seismic reflection profiles, is the

987 OCB.

988

989 In the Beaufort Sea and further north along the Canadian Arctic Islands (south of the CBGL), velocities 990 typical of serpentinized mantle (7.4-7.5 km/s) are observed in Canada Basin. A serpentinized zone near

991 the margins is a typical feature of slow or oblique spreading oceans. The slow spreading is consistent 992 with the thin oceanic crust (4-7 km thick) and the deep central axis of the fossil spreading center (up to 2

$993 \mathrm{~km})$. In contrast, on the northwestern edge of Canada Basin, seaward of Northwind Ridge in the vicinity 994 of a high-amplitude magnetic anomaly NoRM A, there are several sonobuoys that have velocities in the $995 \quad 7.2-7.3 \mathrm{~km} / \mathrm{s}$ range. These sonobuoys are also located near the north end of the oceanic zone and close 996 to a region dominated by high amplitude anomalies associated with Alpha Ridge. On this side of Canada 997 Basin, the transitional velocities are interpreted to be typical of a magma rich margin.

999 Regions of thinned continental crustal velocities of variable thickness are inferred around the edges of 1000 Canada Basin. Where identified offshore Alaska and in the northern Canada basin, thinned continental 1001 crust occurs in water depths of 3500 m or greater, indicating it reaches far offshore of the continental 1002 slope. Published long offset refraction profiles, did not record oceanic layer 3 velocities supporting our 1003 interpretation. In the southeastern part of the basin, continental crust extends minimally offshore. The 
1004 deep crust at ${ }^{\circ} \mathrm{N}$ basin with a single continental crustal velocity is a distinctive feature on the gravity map.

1005 This isolated feature with a significant sedimentary section needs further investigation.

1006 Offshore of the Alaska margin, a broad region with velocities and thickness appropriate for thinned

1007 continental crust is predicted from the velocity determinations of the sonobuoy data. Furthermore, the

1008 magnetic signature in this region has longer wavelengths than observed elsewhere in Canada Basin and

1009 may be an offshore continuation of the broad high-amplitude magnetic anomaly domain (D3) that

1010 onshore is associated with thick continental crust, high mafic crustal content, and possibly strong

1011 lithosphere.

1012

1013 The most popular hypothesis for the opening of Canada Basin is a counterclockwise rotation of Alaska

1014 away from the Canadian Polar margin. The magnetic anomalies in the limited oceanic crust area are

1015 consistent with this model. However, although oceanic crust is nearly symmetrically about the CBGL, the 1016 asymmetrical distribution of the oceanic crust with respect to the margins indicates that a more

1017 complicated plate tectonic model is needed to explain the observed data.

1018

10197 Acknowledgements

1020 The officers and crews of the CCGS Louis S. St Laurent and the USCGC Healy are thanked for their tireless

1021 efforts in the ice choked waters of the Arctic Ocean in support of the scientific program. The experience,

1022 skill and unflagging support of the seagoing technical team lead by Borden Chapman were the key to the

1023 success of the program. Funding for this work was provided through the Geological Survey of Canada as

1024 part of the Canada's Extended Continental Slope (ECS) Program. This is ESS contribution no. 20150409.

1025 Funding for this work was also provided in part through the U.S. Geological Survey as part of the U.S.

1026 ECS Project. This article has been peer reviewed and approved for publication consistent with U.S.

1027 Geological Survey Fundamental Science Practices (http://pubs.usgs.gov/circ/1367/). Trade names are 
1028 used for descriptive purposes only and do not imply endorsement by either the U.S. Geological Survey 1029 or the Geological Survey of Canada.

1030

1031 The manuscript was internally reviewed by P. Potter and P. Hart. In addition, this manuscript was

1032 improved through critical reviews of V. Childers, W. Jokat and L. Lane.

1033 


\section{8 References}

1035 Alvey, A., Gaina, C., Kusznir, N.J., and Torsvik, T.H., 2008. Integrated crustal thickness mapping and plate 1036 reconstructions for the high Arctic. Earth Planet. Sci. Lett., 274, 310-321.

1037

Andersen, O.B., Knudsen, P., and Berry, P.M .A., 2010. The DNSC08GRA global marine gravity field from

1038 double retraced satellite altimetry. J. Geod., 84, 191-199. doi 10.1007/7s00190-009-0355-9.

1039

1040

1041

1042

1043

1044

1045

1046

1047

1048

1049

1050

1051

1052

1053

1054
Andronikov, A.V., M ukasa, S.B., M ayer, L.A., and Brumley, K., 2008. First recovery of Submarine Basalts from the Chukchi Borderland and Alpha-M endeleev Ridge Region, Arctic Ocean (abs.). AGU Fall Meeting, V41D-2124 (poster).

Baggeroer A., and Falconer, R.H.K., 1982. Array refraction profiles and crustal models of the Canada Basin. J. Geophys. Res., 81, 5461-5476.

Berry, M.J., and Barr, K.G., 1971. A seismic refraction profile across the polar continental shelf of the Queen Elizabeth Islands. Can. J. Earth Sci., 8, 347-360.

Blaich, O.A., Faleide, J.I., and Filippos, T., 2011. Crustal breakup and continent-ocean transition at South Atlantic conjugate margins, J. Geophys. Res., 116, B01402, doi:10.1029/2010JB007686.

Bleeker, W., Kamo, S., Söderlund, U., and Ernst, R.E., 2012. A precise U-Pb baddeleyite age of $121.02 \pm 0.25 \mathrm{M}$ a for a dolerite sill associated with the radiating Queen Elizabeth (Lightfoot River) dyke swarm, Canadian Arctic. Report A107, 12 p., unpublished. In: Ernst, R.E., Bleeker, W., and LIPs reconstruction project team, 2013. Reconstruction of supercontinents back to $2.7 \mathrm{Ga}$ using the Large Igneous Province (LIP) Record: With implications for mineral deposit targeting, hydrocarbon exploration, and Earth system evolution-Year 3 Summary for Project Sponsors. Available upon request to the first author. 
1055 Bown, J.W., and White, R.S., 1994. Variation with spreading rate of oceanic crustal thickness and 1056 geochemistry. Earth and Planetary Science Letters, 12, 435-449.

1057 Bronner, A., Sauter, D., M anatschal, G., Peron-Pinvidic, G., and M unschy, M., 2011. Magmatic breakup as an explanation for magnetic anomalies at magma-poor rifted margins. Nature Geoscience, 4, 549-553.

1060 1061

1062
Brozena, J.M ., Childers, V.A., Lawver, L.A., Gahagan, L.M., Forsberg, R., Faleide, J.I., and Eldholm, O., 2003. New aeromagnetic study of the Eurasia Basin and Lomonosov Ridge: implications for basin development. Geology, 31, 825-828.

Brumley, K., M iller, E.L., Konstantinou, A., Grove, M., M eisling, K.E., and M ayer, L.A., 2015. First bedrock samples dredged from submarine outcrops in the Chukchi Borderland, Arctic Ocean. Geosphere, 11 (2): 76-92, (doi.10.1130/GES01044.1).

Cannat, M., Sauter, D., Mendel, V., Ruellan, E., Okino, K., Escartin, J., Combier, V., and Baala, M., 2006. Modes of seafloor generation at a melt-poor ultraslow-spreading ridge. Geology, 34, 605-608.

Chian, D., Keen, C.E., Reid, I., Louden, K.E., 1995. Evolution of nonvolcanic rifted margins: new results from the conjugate margins of the Labrador Sea. Geology, 23, 589-592.

Chian, D., and Lebedeva-Ivanova, N., 2015. Atlas of Sonobuoy Velocity Analyses in Canada Basin; Geol. Survey Can. Open File. 7661: 55p., 1. zip file. doi: 10.4095/295857. http://geoscan.nrcan.gc.ca

Chian, D., Louden, K.E., M inshull, T.A., and Whitmarsh, R.B., 1999. Deep structure of the oceancontinent transition in the southern Iberia Abyssal Plain from seismic refraction profilers: Ocean Drilling Program (Legs 149and 173) transect. J. Geophys. Res., 104, 7443-7462. 
1075 Christensen, N.K., 2004. Serpentinites, Peridotites, and Seismology: International Geology Review, 46, 1076 795-816.

1077 Churkin, M., and Trexler, J.H. Jr., 1980. Circum-Arctic Plate Accretion - Isolating part of a Pacific Plate to 1078 form the nucleus of the Arctic Basin: Earth Planet. Sci. Lett., 48, 356-362.

1079 Clark, S.A., Sawyer, D.S., Austin, J.A., Christeson, G.L., Nakamura, Y., 2007. Characterizing the Galicia $1080 \quad$ Bank-Southern Iberia abyssal plain rifted margin segment boundary using multichannel seismic 1081 and ocean bottom seismometer data. J. Geophy. Res., 112, B03408, doi:10.1029/2006JB004581 $108217 \mathrm{pp}$.

1083 Corfu, F., Polteau, S., Planke, S., Faleide, J-I., Svensen, H., Zayoncheck, A., and Stolbov., N., 2013. U-Pb 1084 geochronology of Cretaceous magmatism on the Svalbard and Franz Josef Land, Barents Sea 1085 Large Igneous Province, Geology Magazine 150, 1127-1135.

$1086 \quad$ http://dx.doi.org/10.1017/S0016756813000162

1087 Dean, S.M., M inshull, T.A., Whitmarsh, R.B., and Louden, K.E., 2000. Deep structure of the ocean1088 continent transition in the southern Iberia Abyssal Plain from seismic refraction profiles: the 1089 IMA-9 transect at $40^{\circ} 20^{\prime}$ N. J. Geophy. Res., 105, 5859-5885.

1090 Dick, H.J.B., Lin, J., and Schouten, H., 2003. An ultraslow-spreading class of ocean ridge. Nature, 426, $1091 \quad 405-412$.

1092 Divins, D.L., 2003. Total Sediment Thickness of the World's Oceans \& M arginal Seas, NOAA National 1093 Geophysical Data Center, Boulder, Co. 
1094 Døssing, A., Jackson, H. R., M atzka, J., Einarrson, I., Rasmussen, T.M., Olesen, A.V., and Brozena, J.M.

1095

1096

1097

1098

1099

1100

1101

1102

1103

1104

1105

1106

1107

1108

1109

1110

1111

1112

1113

1114 2013. On the origin of the Amerasia Basin and the High Arctic Large Igneous Province - Results of new magnetic data. Earth Planet. Sci. Lett., 363, 219-230.

Ehlers, B-M ., and Jokat, W., 2009. Subsidence and crustal roughness of ultra-slow spreading ridges in the North Atlantic and Arctic Ocean. Geophys. J., 177, 451-462.

Embry A.F., 1990. Geological and geophysical evidence in support of anti-clockwise rotation of northern Alaska. Geology, 93, 317-329.

Embry, A.F., 1991. M esozoic history of the Arctic Islands, Chapter 14, In: Trettin H.P. (Ed.), Geology of the Innuitian Orogen and Arctic Platform of Canada and Greenland: Geological Survey of Canada, Geology of Canada no. 3, (also Geological Society of America, The Geology of North America, v. E), 371-433.

Embry, A.F., and Osadetz, K.G., 1988. Stratigraphy and tectonic significance of Cretaceous volcanism in the Queen Elizabeth Islands, Canadian Arctic Archipelago. Canadian Journal of Earth Sciences, 25, p. 1209-1219.

Embry A.F., and Dixon J., 1990. The breakup unconformity of the Amerasia Basin, Arctic Ocean: evidence from Arctic Canada. Geological Society of America Bulletin, 102, 1526-1534.

Embry, A., and Dixon, J., 1994. The age of the Amerasia Basin. 1992, International Conference on Arctic Margins Proceedings, 289-294.

Estrada, S., 2015. Geochemical and Sr-Nd isotope variations within the Cretaceous continental flood basalt suites of the Canadian High Arctic, with a focus on the Hassel Formation basalts of northeast Ellesmere Island. Int. J. Earth Sci., 104, 1981-2005 doi:10.1007/s00531-014-1066-x. 
1115 Estrada, S., and Henjes-Kunst, F., 2004. Volcanism in the Canadian High Arctic related to the opening of 1116 the Arctic Ocean. Zeitschrift der Deutschen Geologischen Gesellschaft, 154, 579-603.

1117 Evain, M., Afilhado, A., Rigoti, C., Loureiro, A., Alves, D., Klingelheefer, F., Schnurle, P, Feld, A., Fuck, R., 1118 Soares, J., Vinivius de Lima, M., Corela, C., Matias, L, Benabdellouahed, M., Baltzer, A., Rabineau, 1119 M, Viana, A., M oulin, M., and Asianian, D., 2015. Deep structure of the Santos Basin-Sao Paulo Plateau System, SE Brazil: J. Geophys. Res., 120(8), 5401-5431, doi:10.1002/2014JB011561.

1121 Evenchick, C.A., Davis, W.J., Bedard, J.H., Hayward, N., and Friedman, R.M., 2015. Evidence for protracted High Arctic large igneous province in the central Sverdrup Basin from stratigraphy, geochronology, and paleodepths of saucer-shaped sills: GSA Bulletin, 127 (9/10), doi: 10.1130B31190.1, 1366-1390.

1125 Funck T., Andersen, M.S., Keser Neish, J., Dahl-Jensen, T., 2008. A refraction seismic transect from the 1126 Faroe Islands to the Hatton-Rockall Basin, J. Geophys. Res., 113, B12405, doi:10.1029/2008|B005675, 25 pp.

1128 Funck, T., Jackson, H.R., and Shimeld, J., 2011. The crustal structure of the Alpha ridge at the transition to the Canadian Polar margin: results from a seismic refraction experiment, J. Geophys. Res., 116, B1201, doi:10,1029/20/2011jb008411,20118.

1131 Gaina, C., Saltus, R., CAM P-GM group, and the CAM P-geology group 2014. Circum-Arctic mapping 1132 project: New magnetic anomalies linked to the geology of the Arctic. ResearchGate, 5.

1133 Gottlieb, E.S., M eisling, K.E., M iller, E.L., and M ull, C.G., 2014. Closing the Canada Basin: Detrital zirxon 1134 geochronology relationships between the North Slope of Arctic Alaska and the Franklinian 1135 mobile belt of Arctic Canada. Geosphere, 10, 1366-1384. 
1136 Grantz, A., Eittreim, S., and Dinter, D.A., 1979. Geology and tectonic development of the continental 1137 margin north of Alaska. Tectonophysics, 59, 263-291.

1138 Grantz, A., M ay, S.D., and Hart, P.E. 1994. Geology of the Arctic continental margin of Alaska. In: Plafker, 1139 G., and Berg, H.C. (Eds.), The Geology of Alaska: Boulder, Colorado, Geological Society of $1140 \quad$ America, The Geology of North America, v. G-1, 17-48.

1141 Grantz, A., Hart, P.E., and Childers, V.A., 2011. A geology and tectonic development of the Amerasia and 1142 Canada Basins, Arctic Ocean Chapter 50. In: Spencer, A.M ., Embry, A.M., Gautier, D.L., 1143 Stoupakova, A.V., and Sorensen, K. (Eds.), Arctic Petroleum Geology, Geological Society of $1144 \quad$ London Memoir, v. 35, p. 771-799, doi:10.1144/M 35.

1145 Hall J.K., 1990. Chukchi Borderland. In: Grantz, A., Johnson L., and Sweeney, J.F. (Eds.), The Arctic Ocean 1146 Region. Boulder, Geological Society of America, 593-616.

1147 Harrison, J.C., and Brent, T.A., 2005. Basins and fold belts of Prince Patrick Island and adjacent areas, 1148 Canadian Arctic Islands. Geological Survey of Canada Bulletin, 560, 198pp.

1149 Helwig, J., Kumar, N., Emmet, P., and Dinkleman, M.G., 2011. Regional seismic interpretation of crustal 1150 framework, Canadian Arctic passive margin, Beaufort Sea, with comments on petroleum potential, In: Spencer, A. M., Embry, A. F., Gautier, D. L., Stoupakova, A. V., and Sørensen, K. (Eds.), Arctic Petroleum Geology: Geological Society, London, M emoir 35, 527-543.

1153 Hermann, T., and Jokat, W., 2013. Crustal structure of the Boreas Basin and the Knipovich Ridge at $76^{\circ} \mathrm{N}$ 1154 in the North Atlantic, Geophysical Journal International, 193(3), 1399-1414, doi:

$1155 \quad$ 10.1093/gji/ggt048. 
1156 Houseknecht, D.W., and Bird, K.J., 2011. Geology and petroleum potential of the rifted margins of the

1157 Canada Basin, In: Spencer, A. M., Embry, A. F., Gautier, D. L., Stoupakova, A. V., and Sørensen, K. 1158 (Eds.), Arctic Petroleum Geology. Geological Society, London, M emoirs 3, 509-526.

1159 Hubbard, R.J., Edrich, S.P., and Rattey, R.P., 1987. Geologic evolution and hydrocarbon habitat of the $1160 \quad$ Arctic Alaska M icroplate. Marine and Petroleum Geology, 4, 2-34.

1161 Hutchinson, D.R., M osher, D., Shimeld, J., Jackson, R., Lebedeva-Ivanova,N. and Chian, D., 2012.

1162 Basement morphology of the Canada Basin, Arctic Ocean: Tromso, Norway, Arctic Frontiers, 23-

27 January, 2012: full presentation at:

1164 http://www.arcticfrontiers.com/index.php?option=com docman\&task=doc download\&gid=68 $1165 \quad$ 0\&ltemid $=389 \&$ lang=en

1166 Jackson, H.R., Grantz, A., Reid, I. M ay, S.D., and Hart, P.E., 1995. Observations of anomalous crust in the 1167 Canada Basin. Earth and Planetary Science Letters, 134, 99-106.

1168 Jokat, W., 2003. Seismic investigations along the western sector of Alpha Ridge Central Arctic Ocean. 1169 Geophys. J. Int., 152, 185-201.

1170 Jokat, W., Ritzmann, O., Schmidt-Aursch, M.C., Drachev, S., Gauger, S., and Snow J., 2003. Geophysical 1171 evidence for reduced melt production on the Arctic ultraslow Gakkel mid-ocean ridge. Nature, $1172 \quad$ 423, 962-965.

1173 Jokat, W., and Schmidt-Aursch,M.C., 2007. Geophysical Characteristics of the ultraslow spreading Gakkel 1174 Ridge, Arctic Ocean. Geopys. J. Int., 168, 983-998. 
1175 Jokat, W., Kollofrath, J., Geissler, W., and Jensen, L., 2012. Crustal thickness and earthquake distribution 1176 south of the Logachev Seamount, Knipovich Ridge, Geophysical Research Letters, 39, L08302, 1177 doi:10.1029/2012GL051199.

1178 Jokat, W., Ickrath M., and O'Connor J., 2013. Seismic transect across the Lomonosov and M endeleev 1179 Ridges: Constraints on the geological evolution of the Amerasia Basin, Arctic Ocean. Geopys. 1180 Res. Lett., 40, 5047-5051.

1181 Kandilarov, A., Landa, H., M jede, R., Pedersen, R.B., Okino, K., and M urai, Y., 2010. Crustal structure of 1182 the ultra-slow spreading Knipovich Ridge, North Atlantic, along a presumed ridge segment 1183 center. Marine Geophysical Research, 31, 173-195.

1184 Karner, G.D., Johnson, C.A., M ohn, G., and M anatschal, G., 2012. Depositional environments and source 1185 distribution across hyper-extended rifted margins of the North Atlantic: Insights from the Iberia1186 Newfoundland margin. Third Conjugate M argins Conference, Dublin, Ireland, 22-24 August, $1187 \quad$ 2012, p. 7-19.

1188 Lane, L., 1997. Canada Basin, Arctic Ocean: Evidence against a rotational origin. Tectonics, 16: 363-387.

1189 Lane, L.S., Gehrels, G.E., and Layer, P.W., 2015. Provenance and paleography of the Neurokpuk 1190 Formation, northwest Laurentia: An integrated synthesis Geological Society of America Bulletin, 1191 v. 128, no.1-2, p.239-257, doi: 10.1130/B31234.1

1192 Lavier, L.L., and M anatschal, G., 2006. A mechanism to thin the continental lithosphere at magma-poor 1193 margins, Nature, 440, doi:10.1038, 324-328. 
1194 Lawver L.A., Scotese C.R., 1990. A review of tectonic models for the evolution of Canada Basin. In:

1195 Grantz, A., Johnson, L., and Sweeney, J.F. (Eds.), The Arctic Ocean Region. Boulder, Geological $1196 \quad$ Society of America, 593-618.

1197 Lawver, L.A., Grantz, A., and Gahagan, L. M., 2002. Plate kinematic evolution of the present Arctic region 1198 since the Ordovician. In: M iller, E. L., Grantz, A., and Klemperer, S. (Eds.), Tectonic Evolution of 1199 the Bering Shelf-Chukchi Sea-Arctic M argin and Adjacent Landmasses. Geological Society of $1200 \quad$ America, Boulder, CO, Special Papers, 360: 333-358.

1201 Laxon, S., and M cAdoo, D., 1994. Arctic Ocean gravity field derived from ERS-1 Satellite Altimetry. $1202 \quad$ Science, 265, 621-624.

1203 Lebedeva-Ivanova, N., and Lizaralde, D., 2011. An empirical direct-wave travel time equation for Arctic 1204 Sonobuoy data (abs.) ICAM VI, www2.gi.alaska.edu/ICAM IV/Abstracts/Abstracts.htm

1205 Lundin, E.R., and Doré, A.G., 2011. Hyperextension, serpentenization, and weakening: a new paradigm 1206 for rifted margin compressional deformation. Geology, 39, 347-350.doi: 10.1130/G31499.1.

1207 Ludwig, W.F., Nafe, J.E., and Drake, C.L., 1970. Seismic refraction In: Maxwell, A.E. (Ed.), The Sea, v. 4, 1208 53-84, Wiley Interscience, New York.

1209 MacDonald, K.C., 1982. M id-Ocean Ridges: fine scale tectonic, volcanic and hydrothermal processes 1210 within the plate boundary zone. Annual Review of Earth and Planetary Sciences, 10, 155-190.

1211 Maher, H.D., 2001. M anifestations of the Cretaceous High Arctic Large Igneous Province in Svalbard: $1212 \quad$ Journal of Geology, 109, 91-104.

1213 Mair, J. A., and Lyons, J.A., 1981. Crustal structure and velocity anisotropy beneath the Beaufort Sea. 1214 Can. J. Earth Sci., 18, 724-741. 
1215 Malinverno, A., 1991. Inverse square-root dependence of mid-ocean ridge flank roughness on spreading 1216 rate. Nature, 352, 58-60.

1217 Mjelde, R., Kasahara, J., Shimamura, H., Kamimura, A., Kanazawa, T., Kodaira, S., Raum, T., and Shiobara, 1218 H., 2002. Lower crustal seismic velocity-anomalies; magmatic underplating or serpentinized 1219 peridotite? Evidence from the Voring Margin, NE Atlantic: Mar. Geophys. Res., 23, 169-183.

1220 Mjelde, R., Raum, T., M yhren, B., Shimamura, H., M urai, Y., Takanami, T., Karpuz, R., and Næss, U., 1221 2005, JGR, Continent-ocean transition on the Vøring Plateau, NE Atlantic, derived from densely 1222 sampled ocean bottom seismometer data. J. Geophys. Res., 110, B05101, 1223 doi:10.1029/2004JB003026.

1224 Mohn, G., M anatschal, G., Beltrando, M., M asini, E., and Kusznir, N., 2012, Necking of continental crust 1225 in magma-poor rifted margins: evidence from the fossil Alpine Tethys margins: Tectonics, 31, 1226 TC1012, doi: 10.1029/2011TC002961, 28 p. Mosher, D., Chapman, C.B., Shimeld, J., Jackson, 1227 H.R., Chian, D., Verhoef, J., Hutchinson, D., Lebedeva -Ivanova, N., and Pedersen, R., 2013. High 1228 Arctic Marine Geophysical Acquisition: The Leading Edge, May, 936-943.

1229 Mukasa, S., Andronikov, A., M ayer, L.A., and Brumley, K., 2009. Submarine basalts from the 1230 Alpha/M endeleev Ridge and the Chukchi Borderland (abs.) Geochemistry of the intraplate lavas 1231 recovered from the Arctic Ocean. Geochemica et Cosmochimica Acta, 73 (13) Supplement912.

1232 Müller, R.D., Sdrolias, M., Gaina, C., and Roest, W., 2008. Age, spreading rates, and spreading 1233 asymmetry of the world's ocean crust. Geochemistry, Geophysics, and Geosystems, 9, 19 pp., 1234 Q04006, doi:10.1029/2007GC001743. 
1235 Peron-Pinvidic, G., M anatschal, G., and Osmundsen, P.T., 2013. Structural comparison of archetypal Atlantic rifted margins: A review of observations and concepts. M arine and Petroleum Geology, $43,21-47$.

1238 Pickup, S.L.B., Whitmarsh, R. B., Fowler, C.M.R., and Reston, T.J., 1996. Insight into the nature of the ocean-continent transition off West Iberia from a deep multichannel seismic reflection profile. Geology, 24, 1079-1082.

1241 Reid, I., and Jackson, H.R., 1981. Oceanic spreading rate and crustal thickness. Mar. Geophys. Res., 5, $1242 \quad 165-172$.

1243 Reston, T.J., 2009. The structure, evolution, and symmetry of the magma-poor rifted margins of the $1244 \quad$ North and Central Atlantic: A synthesis. Tectonophysics, 468, 6-27.

1245 Saltus, R. W., Miller, E.L., Gaina, C., and Brown, P.J., 2011. Regional magnetic domains of the Circum1246 Arctic: a framework for geodynamic interpretation. In: Spencer, A. M., Embry, A. F., Gautier, 1247 D.L., Stoupakova, A. V., and Sørensen, K. (Eds.), Arctic Petroleum Geology. Geological Society of $1248 \quad$ London Memoirs, 35, 49-60, doi:10.1144/M 35.4.

1249 Scrutton, R.A., 1979. On sheared passive continental margins. Tectonophysics, 59(1-4), 293-305

1250 Shatsky, N.S., 1935. Tectonics of the Arctic in Geologiya i polyeznye Severa SSSR: Glavsemorputi, v.1 1251 Geologiya, p.149-168 (in Russian).

1252 Sherwood, K.W., 1992, Stratigraphy, structure, and origin of the Franklinian, northeast Chukchi Basin, 1253 Arctic Alaska plate: Proceedings, 1992 International Conference on Arctic Margins, 245-250 $1254 \quad$ (http://www.boem.gov/ICAM 92-245/). 
1255 Shimeld J., Li Q., Chian, D., Lebedeva-Ivanova, N., Jackson, R., M osher, D., and Hutchinson, D. 2016.

1256 Seismic velocities within the sedimentary succession of the Canada Basin and southern Alpha-

1257 Mendeleev Ridge, Arctic Ocean: evidence for accelerated porosity reduction? Geophys. J. Int., $1258 \quad 204$ (1): 1-20 doi:10.1093/gji/ggv416.

1259 Stein, S., and Wysession, M. 2003. An introduction to Seismology, Earthquakes and Earth Structure. $1260 \quad$ Blackwell Publishing.

1261 Stephenson, R.A., Coflin, K.C., Lane, L.S, and Deitrich, J.R., 1994. Crustal structure and tectonic of the 1262 southeastern Beaufort Sea continental margin: Tectonics, 13, 389-400.

1263 Sutra, E., and M anatschal, G., 2012. How does the continental crust thin in a hyperextended rifted 1264 margin? Insights from the Iberia margin. Geology, 40, 139-142. doi:10.1130/G32786.1.

1265 Taylor, P.T., Kovacs, L.C., Vogt, P.R., and Johnson, G. L., 1981. Detailed aeromagnetic investigations 1266 in the Arctic Ocean, 2. J. Geophys. Res., 86, 6323-6333.

1267 Tegner, M., Storey, M., Holm, P.M., Thorarinsson, S.B., Zhao, X., Lo, C.-H., and Knudsen, M.F., 2011. 1268 Magmatism and Eurekan deformation in the High Arctic Large Igneous Province: 40AR-39Ar 1269 age of Kap Washington Group volcanics, North Greenland: Earth and Planetary Science $1270 \quad$ Letters, 303, 203-214.

1271 Vine, F. J., and Matthews, D. H. 1963. Magnetic anomalies over oceanic ridges. Nature, 199 (4897): 9471272949

1273 Vogt, P.R., Taylor, P.T., Kovacs, L.C., and Johnson, G.L., 1982. The Canada Basin: Aeromagnetic 1274 constraints on structure and evolution. Tectonophysics, 89, 295-336. 
1275 White, R.S., M ackenzie, D., and O’Nions, R.K., 1992. Oceanic crustal thickness from seismic measurements and rare earth element inversions. J. Geophys. Res., 9, B13, 19,683-19,715.

1277 White, R.S., Smith, L.K., Roberts, A.W., Christie, P.A.F., Kusznir, N.J., and the rest of the iSIM M Team, 1278 2008. Lower-crustal intrusion on the North Atlantic continental margin. Nature, 452, 460-464

1279 doi.10.1038/nature06687.

1280 Whitmarsh, R.B., Pinheiro, L.M., M iles, P.R. Recq, M., and Sibuet, J.-C., 1993. Thin crust at the western 1281 Iberian ocean-continent transition and ophiolites. Tectonics, 12(5), 1230-1239.

1282 Whitmarsh, R.B., White, R. S., Horsefiled, S.J., Sibuet, J-C, Recq, M. and Louvel, V., 1996. The continent1283 ocean boundary off the western continental margin of Iberia: Crustal structure of west of Galicia 1284 Bank. J. Geophys. Res., 101, B12, 28,291-28,314.

1285 Whitmarsh, R.B., Dean, S.M., M inshull, T.A., and Tompkins, M ., 2000. Tectonic implications of exposure 1286 of lower continental crust beneath the Iberia Abyssal Plain, Northeast Atlantic Ocean; 1287 geophysical evidence. Tectonics, 19(5), 919-942.

1288 Whitmarsh, R., M anatschai, G., and M inshull, T.A., 2001. Evolution of magma -poor continental margins 1289 from rifting to sea floor spreading. Nature, 413, 150-54.

1290 Zelt, C.A., and Smith, R.B., 1992. Seismic travel time inversion for 2_D crustal structure, Geophysical 1291 Journal International, 10, 16-34, doi:10.1111/j.1365-264X.1992.tb00836.x.

1292 Zelt, C. A., and Forsyth, D.A., 1994. M odelling wide-angle seismic data for crustal structure: Southeast 1293 Grenville Province. J. Geophys. Res., 99, 11, 687-11.704, doi: 10.1029/93JB02764. 


\section{Figure Captions}

1297 Figure 1. a) Location of data in Canada Basin. Oceanic, transitional and continental crustal velocities from analysis of the sonobuoys are marked with white, green and black symbols, respectively. Thin solid black lines: coincident seismic reflection profiles. Yellow/cyan lines: assembled seismic transects shown in the paper. Dotted yellow line: Canada Basin Gravity Low (CBGL). Dotted red lines indicate basement depression. Also shown are previous crustal scale profiles: near Northwind Ridge (Jackson et al. 1995), near Alaskan margin (Baggeroer and Falconer, 1982; Mair \& Lyons, 1981); and across Canadian Arctic margin (Stephenson et al., 1994 and Berry and Barr, 1971). b) Enlargment with sonobuoys labeled. Small labelled grey boxes indicate sonobuoys with undefined crustal type.

Figure 2. Idealized transects of (a) magma-rich (volcanic) passive margin showing the seaward dipping reflections (SDRs), and intruded/underplated body, modified from Blaich et al. (2011); and (b) magma-poor (non-volcanic) margin showing the exhumed continental mantle adjacent to oceanic crust, modified from M ohn et al. (2012). OCB: oceanic-continent boundary, OCT: oceancontinent transition zone. Velocities shown are values used in this paper.

1311 Figure 3. Observed velocity/ depth curves, excluding the sedimentary layers, determined from analyses of the wide angle reflection/refraction data (after Chian and Lebedeva-Ivanova, 2015) are plotted in three groups: a) continental, b) oceanic and c) transitional. The grey zone illustrates the range of velocities compiled for oceanic crust at age of 142-143 M a in North Atlantic Ocean (after White et. al., 1992). The groupings are based on the velocity criteria shown in Table I. 
1316

1317

1318

1319

1320

1321

1322

1323

1324

1325

1326

1327

1328

1329

1330

1331

1332

1333

1334

1335

1336

1337
Second row of boxes show the same curves as the first row but colored and sized for easier labelling.

Figure 4. Sonobuoy 0726, an example with oceanic crustal velocities, is displayed (for location see 726 in red in Figure 1). a) The reflection profile along the model. b) Same shots recorded by the sonobuoy, modelled and plotted by Reduced Normal M ove-Out (NM O) transform such that each wide-angle reflection phase (dotted blue) at zero offset matches exactly with the corresponding event on the refection profile. Sedimentary velocities were modelled by Chian and Lebedeva-Ivanova (2015) and used for modelling deeper arrivals with labels indicating their corresponding velocities. Inset of b) shows crustal refraction phases picked (yellow bars) for statistical error analysis with results shown to its left; every trace is picked. c) 1D velocity/ depth curve at the sonobuoy location. d) Final 2D velocity model from the forward modeling, with 5 sets of ray paths illustrated. Each model layer is parameterized by a linear vertical velocity gradient with no horizontal changes in velocity inside the same layer.

Figure 5. Sonobuoy 1034, an example with transitional crustal velocities, is displayed. See 1034 (in red) in Figure 1 for its location and Figure 4 for caption.

Figure 6. Sonobuoy 1003, an example with continental crustal velocities, is displayed. See 1003 (in red) in Figure 1 for location and Figure 4 for caption.

Figure 7. Magnetic anomaly map of Canada Basin (after Gaina et al., 2011). Sonobuoy models classified as oceanic are shown as white squares, continental as black squares and transitional as blue diamonds. Dashed polygon indicates ocean-continent boundary (OCB). The number of each solid blue line indicates the figure number of the seismic transects. D3 indicates a regional magnetic zone defined by Saltus et al., (2011). Parallel white dots indicate a basement depression. 
1338 Figure 8. Free Air gravity anomaly map of Canada Basin (with onshore Bouguer anomaly; after Andersen et al, 2010). Sonobuoy models classified as oceanic are shown as white squares, continental as black squares and transitional as blue diamonds. Dashed polygon indicates the ocean-continent boundary $(\mathrm{OCB})$. The number of each solid blue line indicates the figure number of the seismic transects. Parallel red dots indicate a basement depression.

1343

1344

1345

1346

1347

1348

1349

1350

1351

1352

1353

1354

1355

1356

1357

1358

1359

1360
Figure 9. Seismic transect across the northernmost Canada Basin (see figure 1 for location). a) Observed magnetic and gravity anomalies (extracted from gridded maps in Figures 7 and 8; CBGL: Canada Basin gravity low. C|C indicates course change. b) Reflection profile (Hilbert transformed) converted to depth using a velocity model based on all available sonobuoy data along the transect; sonobuoy labels plotted on the seafloor; brackets indicate offline stations. The timedepth conversion process includes: assign distance to each trace of reflection profile, digitize seafloor and basement in time domain, and perform time-depth conversion assuming a compaction-oriented exponential velocity function for the sediments in central Canada Basin (region 3; Shimeld et al. 2016). Sonobuoy velocity models from the base of sedimentary section are overlain as solid lines and labels show their corresponding velocities in km/s. HVLC: High velocity lower crust. SDR: Seaward dipping reflectors. Final crustal model is constructed in the depth domain that in general matches all available sonobuoy data. The rectangular area marked on panel b) is enlarged in c) to show details (vertical exaggeration: 7.6:1). Vertical arrows indicate base of sedimentary layers.

Figure 10. Seismic transect across the central Canada Basin (see figure 1 for location). Top: magnetic (blue line) and gravity (red line) anomalies extracted from gridded data in Figures 7 and 8, with computed Free Air gravity anomaly (black line) for M oho constraint. Gravity computation used a velocity-density curve from Ludwig et al. (1970). Computed gravity is DC-shifted by -712 mGal 
1361

1362

1363

1364

1365

1366

1367

1368

1369

1370

1371

1372

1373

1374

1375

1376

1377

1378

1379

1380

1381

1382

and assumes a constant density of $3.3 \mathrm{~g} / \mathrm{cm}^{3}$ underneath the model. Bottom: velocity model overlain by depth-converted reflection profile. Sonobuoy 1021 is indicated in blue to contrast with adjacent instruments. See Figure $9 \mathrm{~b}$ for more description.

Figure 11. Seismic transect across southern Canada Basin (see Figure 1 for location). a) Magnetic (blue line) and gravity (red line) anomalies extracted from gridded data in Figures 7 and 8. C| C indicates course changes. b) Velocity model overlain by depth-converted reflection profile. Sonobuoy 804 is indicated in blue to contrast with adjacent instruments. The rectangular area marked on panel b) is enlarged in c) to show details of deeper reflectors coincident with 7.4 km/s layer (vertical exaggeration: 11:1). See Figure 9b for more description.

Figure 12. Seismic transect from Alaskan margin northward to nearly parallel to Canada Basin Gravity Low (CBGL). Top: magnetic (blue line) and gravity (red line) anomalies extracted from gridded data in Figures 7 and 8. Bottom: the transect combines 4 seismic profiles, crosses continental, transitional and oceanic crust, and shows distinctive features in crustal velocity structures as well as basement morphology. Reflection profiles are brute stack data converted to depth, with positive amplitudes plotted as grey and negative amplitudes as blue. See figures $9 \mathrm{a}$ and 9b for more description.

Figure 13. Seismic reflection profile that overlaps the refraction lines reported in M air and Lyons (1981). The velocities reported by them are plotted in red and the velocities based on our sonobuoy data are in black. Sonobuoy 1002 is categorized as in transitional zone due to an observation of HVLC. But this region is in general continental because: crustal velocity are in the continental range; crust shows consistent reflection characters with regional rotated fault blocks; and it is surrounded by typical continental crust in the vicinity of the shelf. 
1383 Figure 14. Seismic reflection profile that overlaps the refraction lines reported in Baggeroer and Falconer 1384 (1982). The velocities reported by them are shown in red and labeled CANBARX 78.

1385 Figure 15. Interpreted distribution of crustal regions plotted on a) bathymetric, b) gravity and c) 1386 magnetic maps (for colour bars of scale see Figures 1, 8 and 7). The regions are based on the 1387 combination of sonobuoy velocities, magnetic and gravity data, seismic reflection control and 1388 geological context. The area with gray shading is the ocean-continent transition. Its inner limit is 1389 the ocean-continent boundary. The star shows the position of sonobuoy 1013. The red and 1390 yellow dots indicate the position of the Baggeroer and Falconer (1982) and Jackson et al. (1995) 1391 refraction experiments. Abbreviations: CBGL-N is Canada Basin Gravity Low-North, CBGL-S is 1392 Canada Basin Gravity Low-South, M R is Magma Rich, M P is Magma Poor, HALIP is High Arctic $1393 \quad$ Large Igneous Province. 

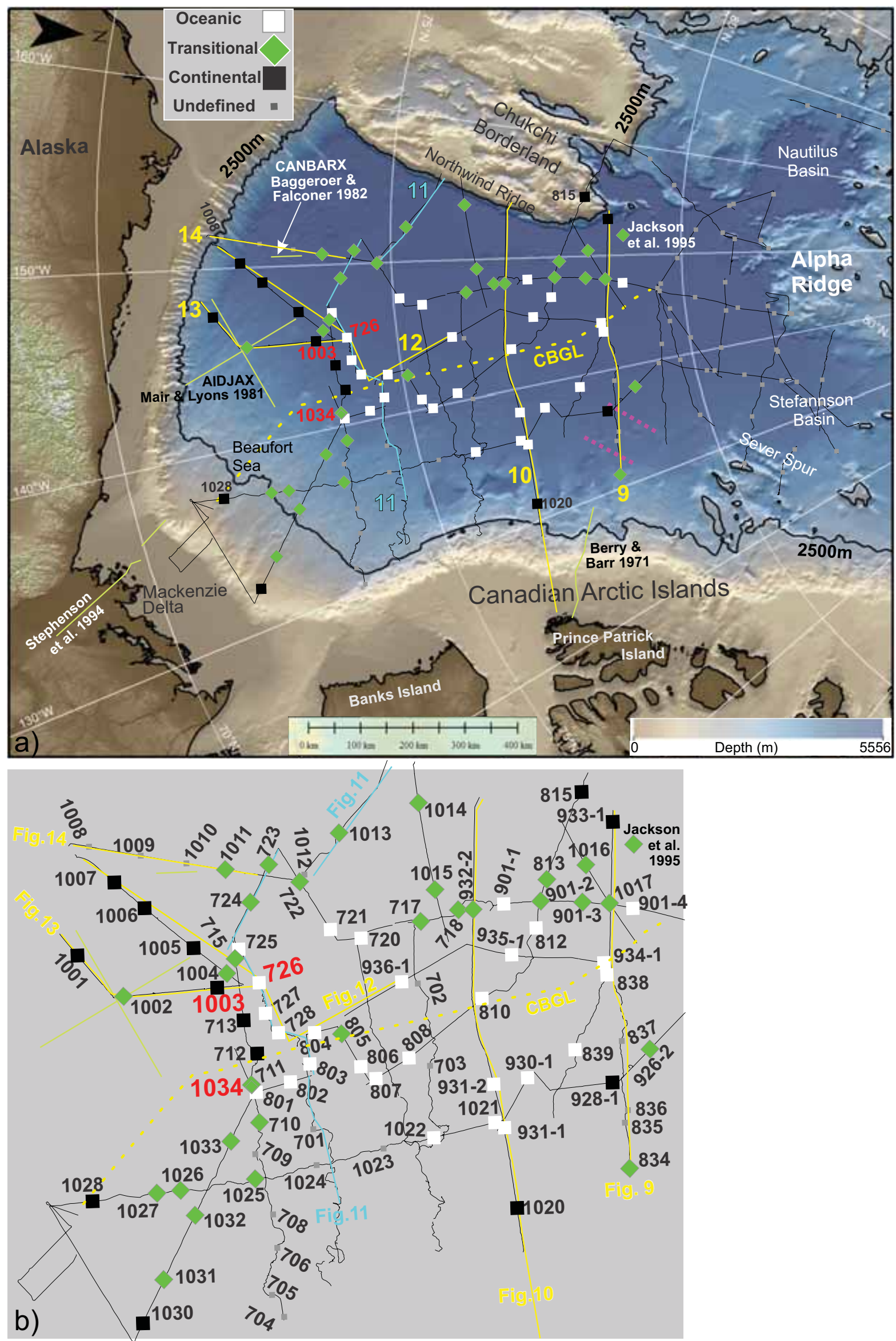

Figure 1. a) Location of data in Canada Basin. Oceanic, transitional and continental crustal velocities from analysis of sonobuoys are marked with white, green and black symbols, respectively. Thin solid black lines: coincident seismic reflection profiles. Yellow/cyan lines: assembled seismic transects shown in paper. Dotted yellow line: Canada Basin Gravity Low (CBGL). Dotted red lines indicate basement depression. Also shown are previous crustal scale profiles: near Northwind Ridge (Jackson et al., 1995), near Alaskan margin (Baggeroer \& Falconer, 1982; Mair \& Lyons, 1981); and across Canadian Arctic margin (Stephenson et al., 1994; Berry \& Barr, 1971). b) Enlargment with sonobuoys labelled. Small labelled grey boxes indicate sonobuoys with undefined crustal type. 


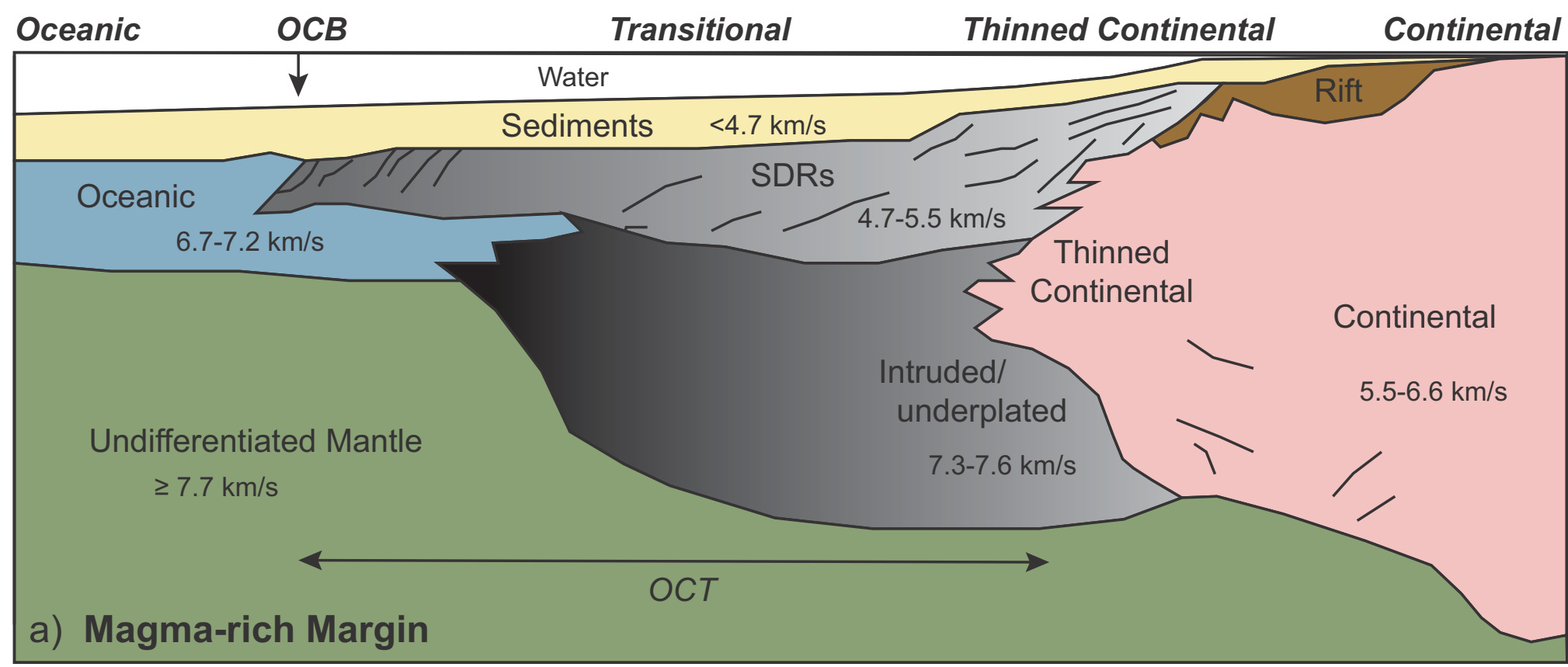

\section{Oceanic Transitional}

Thinned Continental

Continental

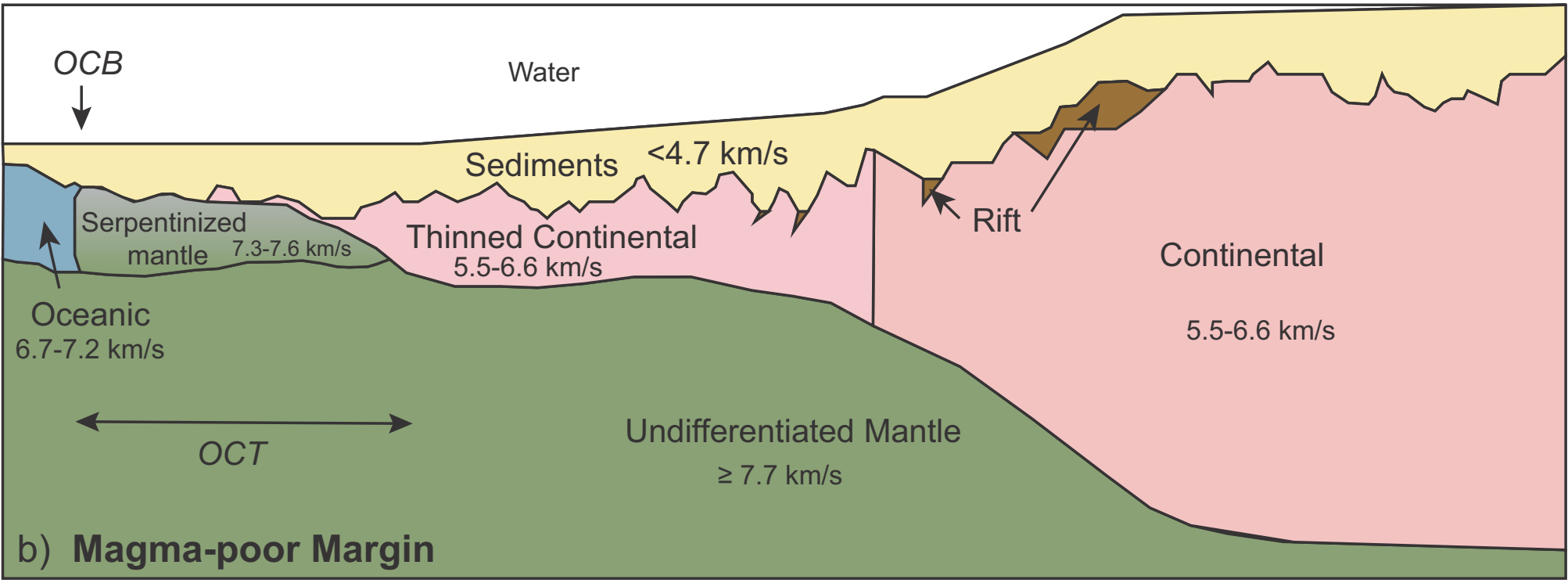

Figure 2. Idealized transects of a) magma-rich (volcanic) passive margin showing seaward dipping reflections (SDRs), and intruded/underplated body, modified from Blaich et al. (2011); and b) magma-poor (nonvolcanic) margin showing exhumed continental mantle adjacent to oceanic crust, modified from Mohn et al. (2012). OCB: oceanic-continent boundary, OCT: ocean-continent transition zone. Velocities shown are values used in this paper. 


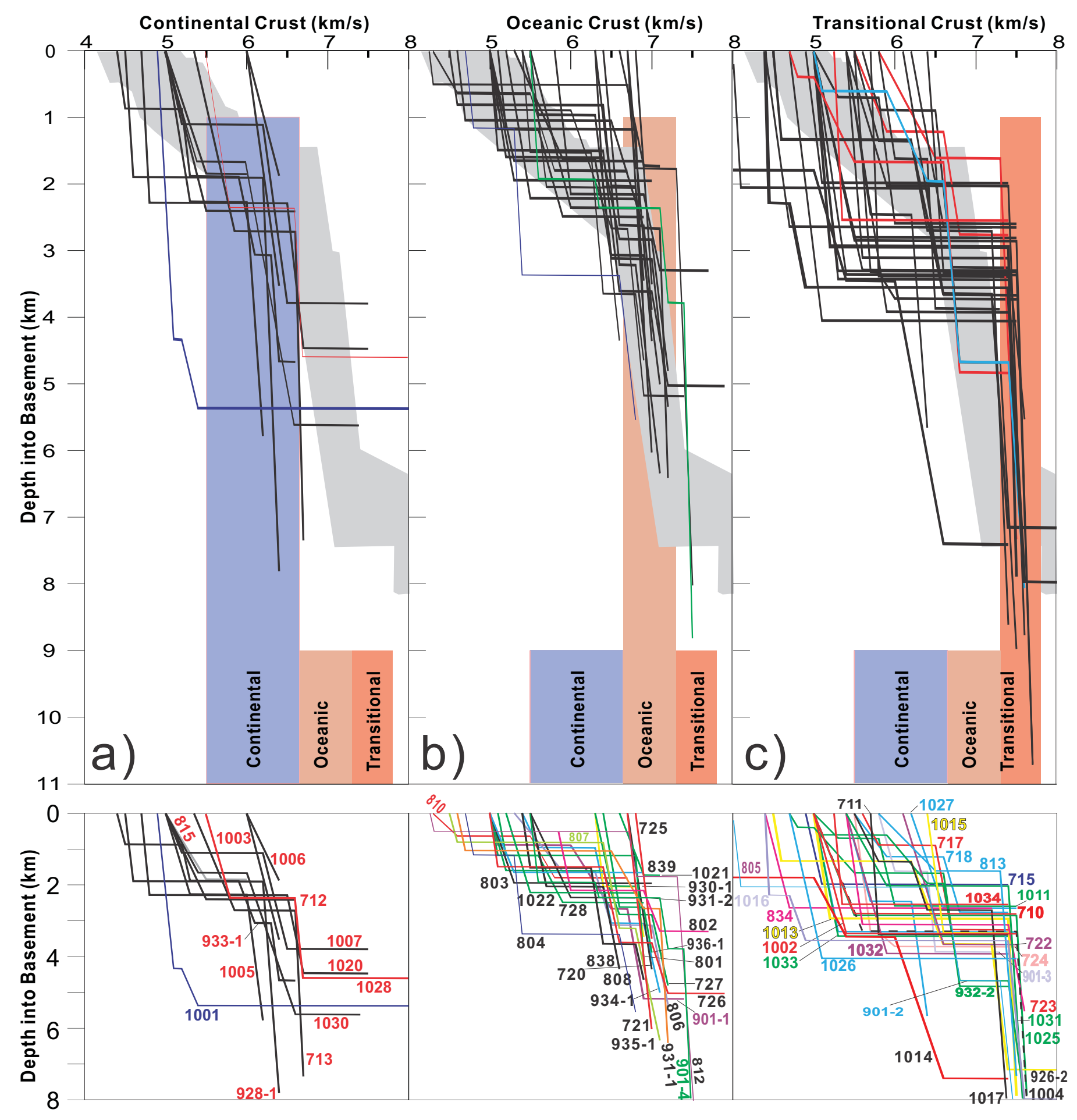

Figure 3. Observed velocity/depth curves, excluding sedimentary layers, determined from analyses of wide angle reflection/refraction data (after Chian and Lebedeva-Ivanova, 2015) are plotted in three groups: a) continental, b) oceanic and c) transitional. The grey zone illustrates the range of velocities compiled for oceanic crust at age of 142-143 Ma in North Atlantic Ocean (after White et. al., 1992). The groupings are based on the velocity criteria shown in Table 1 . Second row of boxes show the same curves as the first row but colored and sized for easier labelling. 


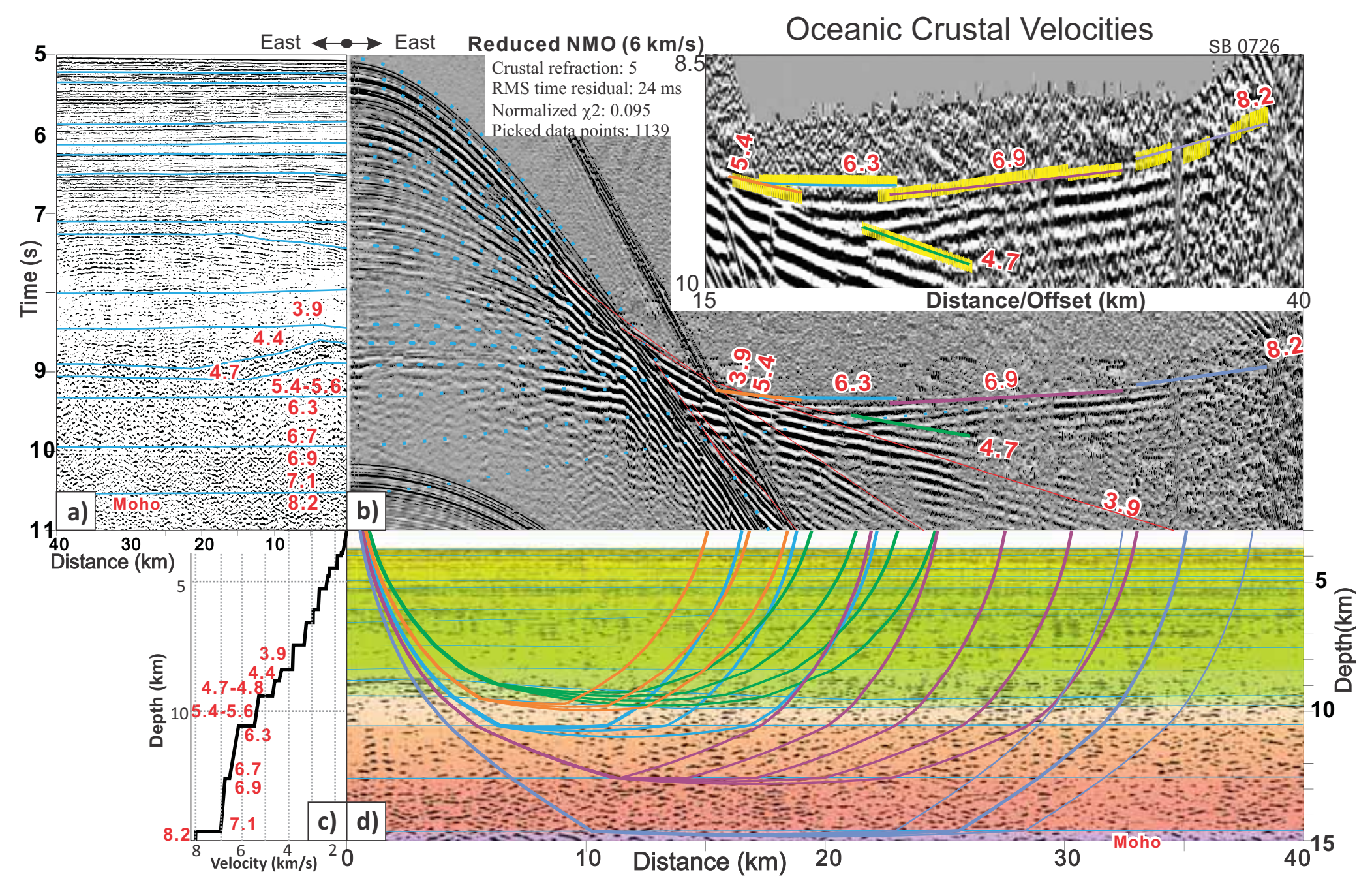

Figure 4. Sonobuoy 0726, an example with oceanic crustal velocities, is displayed (for location see 726 in red in Figure 1). a) Reflection profile along the model. b) Same shots recorded by the sonobuoy, modelled and plotted by Reduced Normal Move-Out (NMO) transform such that each wide-angle reflection phase (dotted blue) at zero offset matches exactly with the corresponding event on refection profile. Sedimentary velocities were modelled by Chian and Lebedeva-Ivanova (2015) and used for modelling deeper arrivals with labels indicating their corresponding velocities. Inset of b) shows crustal refraction phases picked (yellow bars) for statistical error analysis with results shown to its left; every trace is picked. c) 1D velocity/depth curve at sonobuoy location. d) Final 2D velocity model from forward modeling, with 5 sets of ray paths illustrated. Each model layer is parameterized by a linear vertical velocity gradient with no horizontal changes in velocity inside the same layer. 


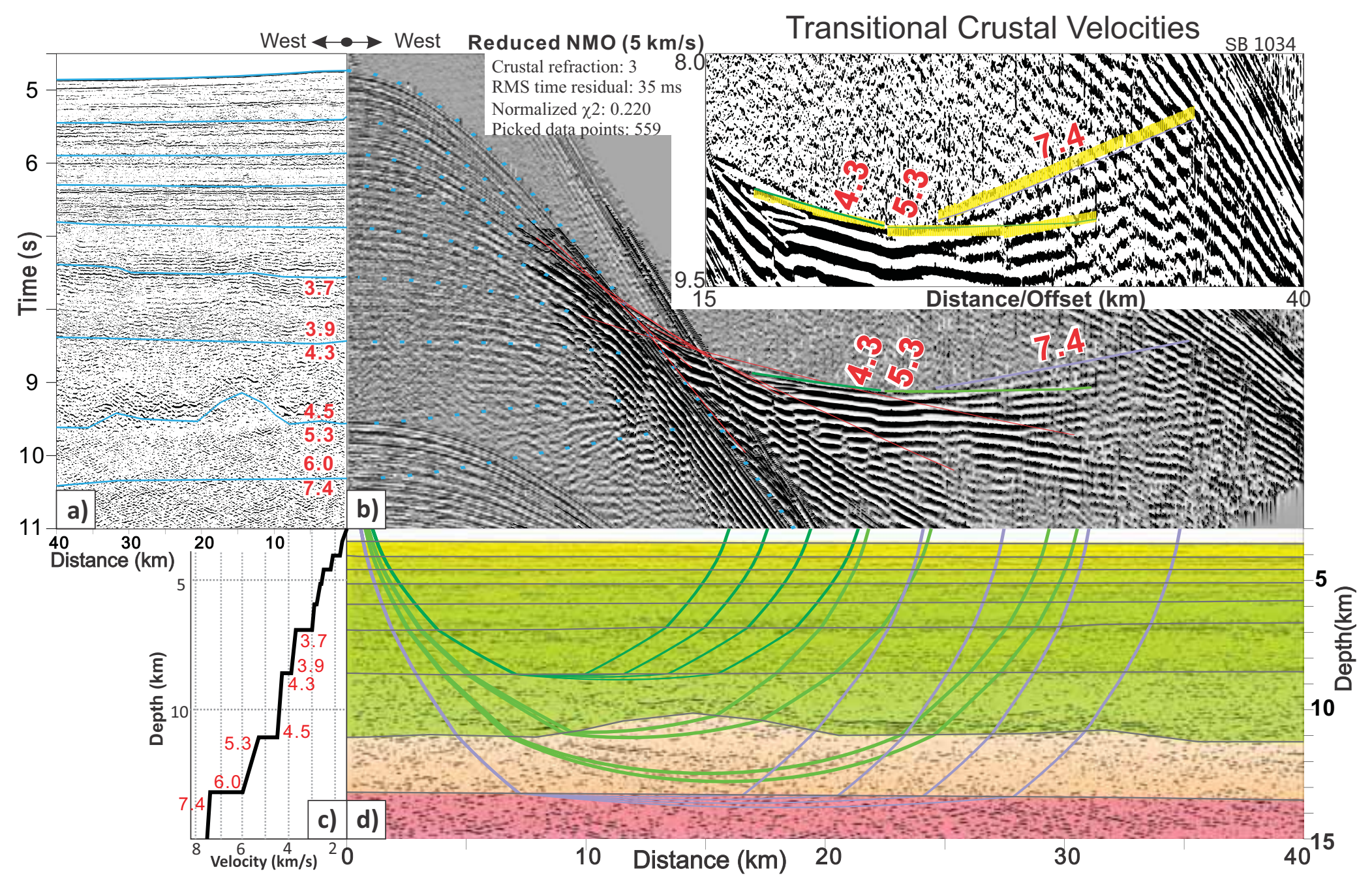

Figure 5. Sonobuoy 1034, an example with transitional crustal velocities, is displayed. See 1034 (in red) in Figure 1 for its location and Figure 4 for caption. 


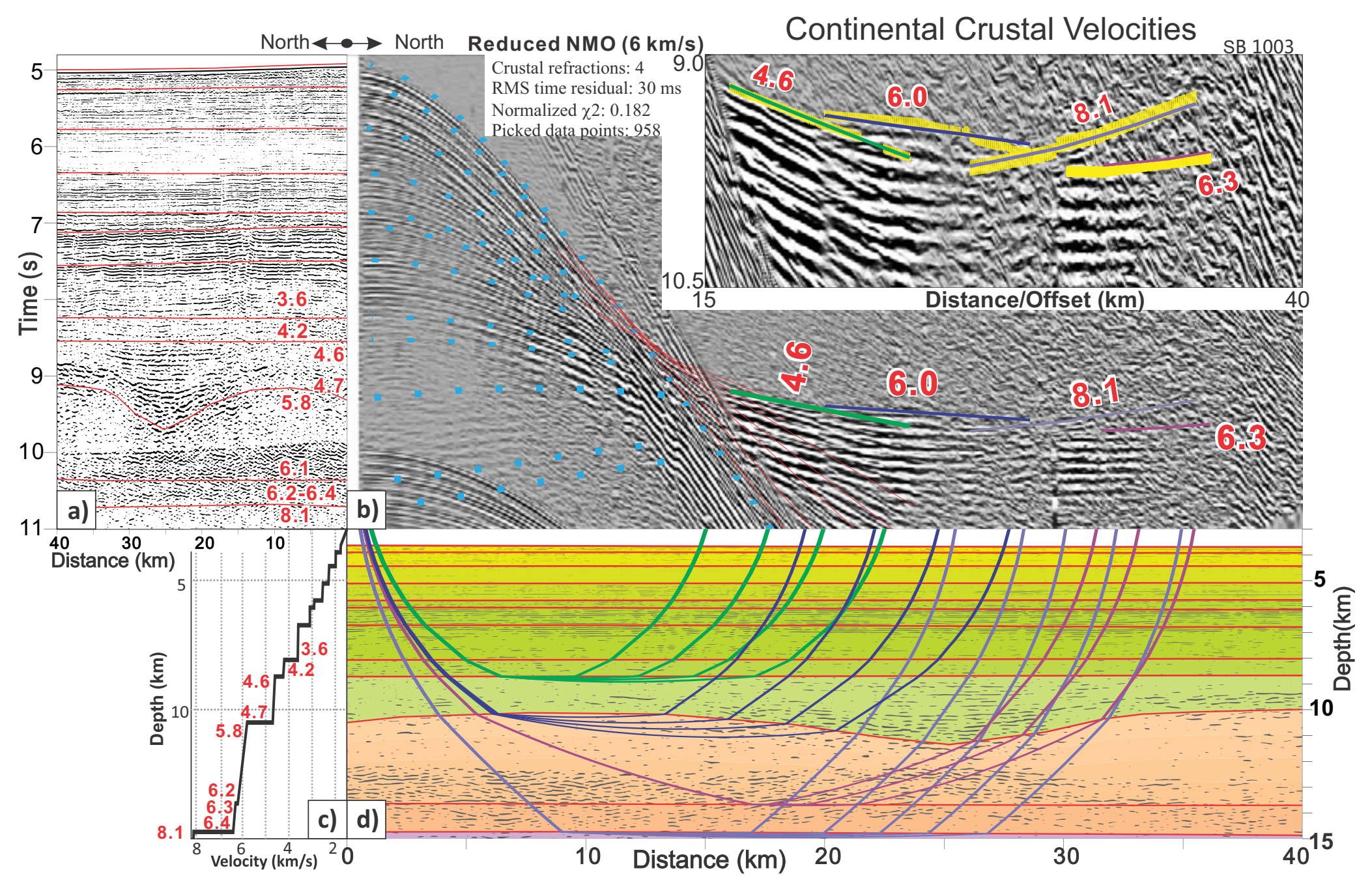

Figure 6. Sonobuoy 1003, an example with continental crustal velocities, is displayed. See 1003 (in red) in Figure 1 for location and Figure 4 for caption. 


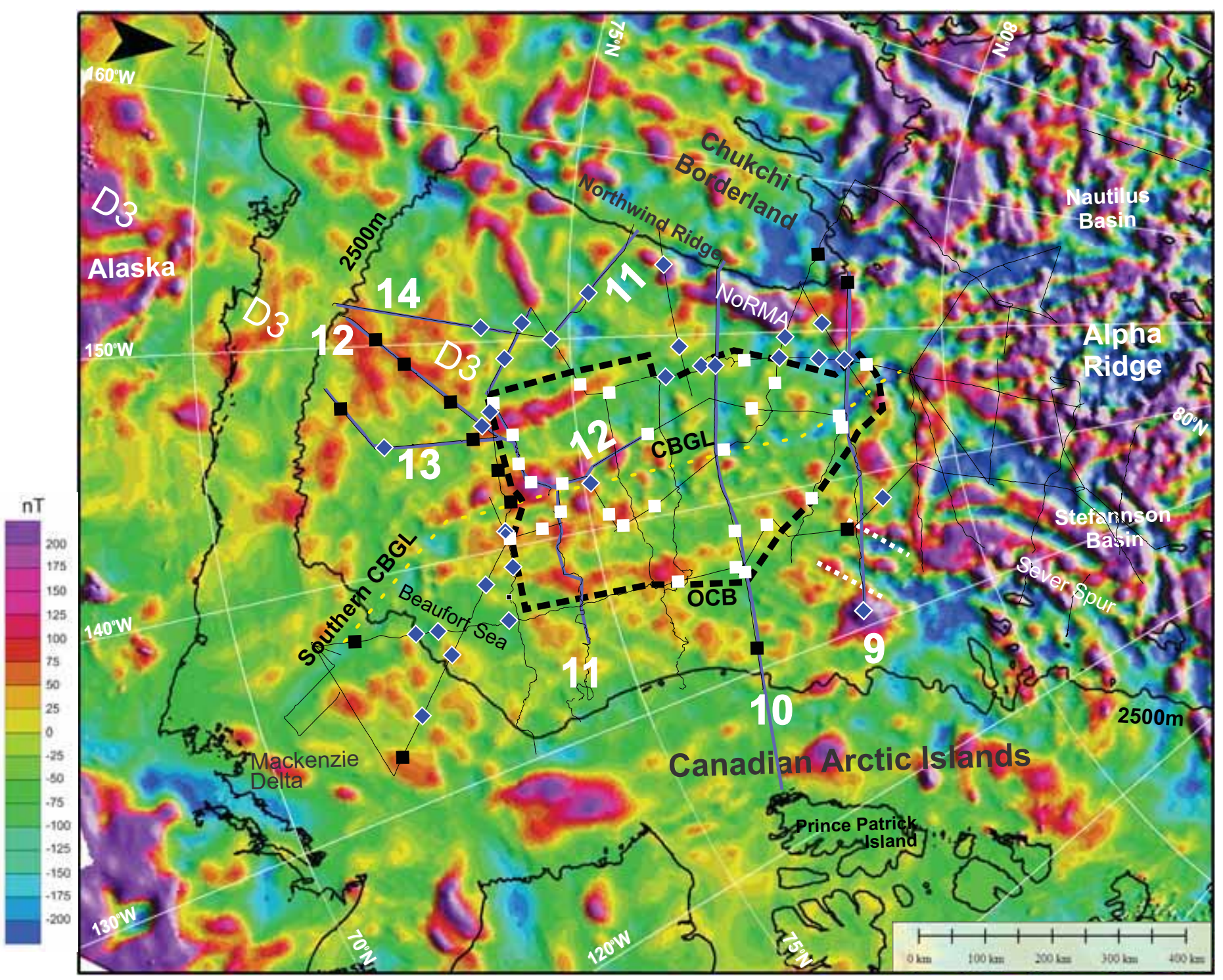

Figure 7. Magnetic anomaly map of Canada Basin (after Gaina et al., 2011). Sonobuoy models classified as oceanic are shown as white squares, continental as black squares and transitional as blue diamonds. Dashed polygon indicates ocean-continent boundary $(O C B)$. The number of each solid blue line indicates figure number of seismic transects. D3 indicates a regional magnetic zone defined by Saltus et al., (2011). Parallel white dots indicate a basement depression. 


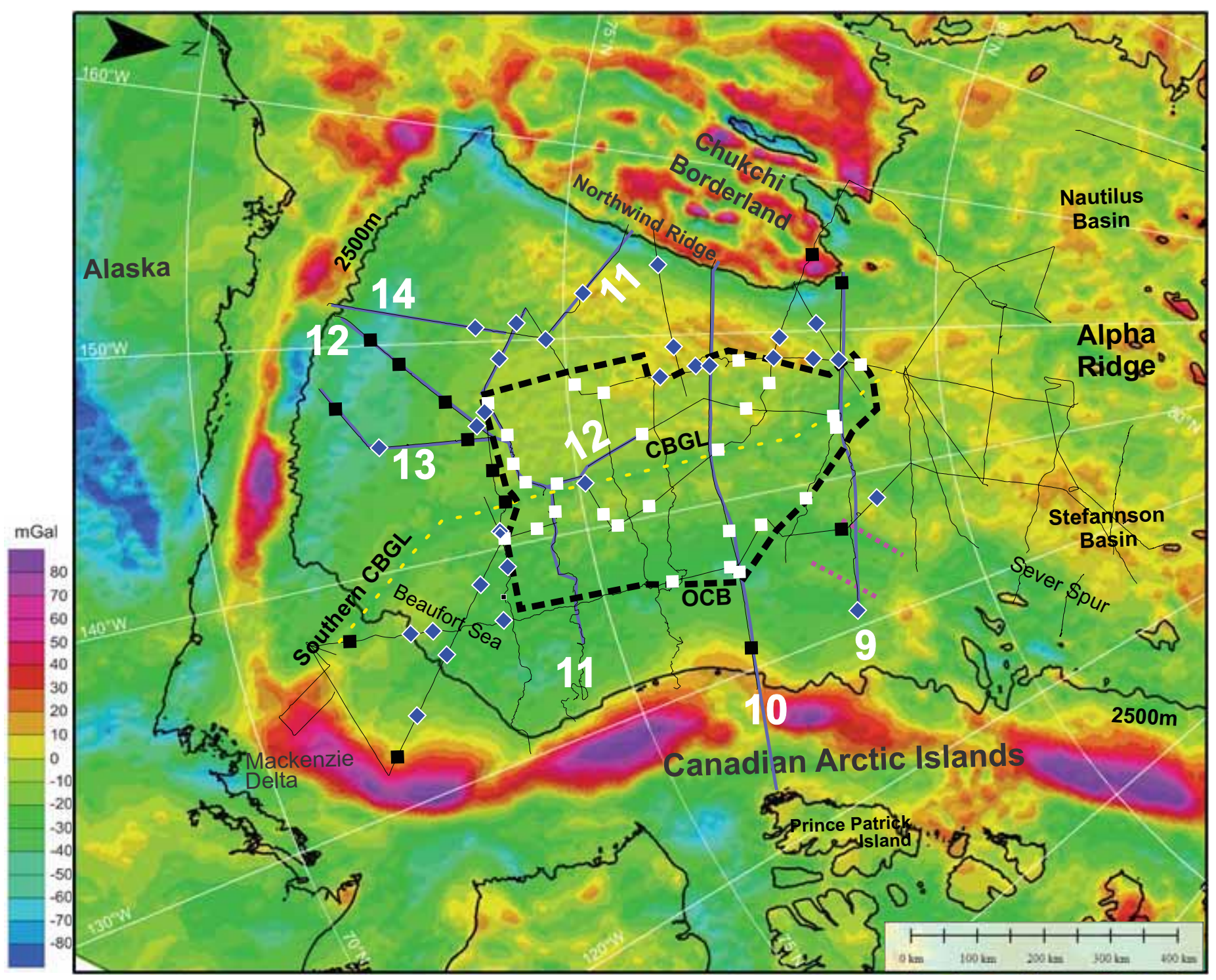

Figure 8. Free Air gravity anomaly map of Canada Basin (with onshore Bouguer anomaly; after Andersen et al., 2010). Sonobuoy models classified as oceanic are shown as white squares, continental as black squares and transitional as blue diamonds. Dashed polygon indicates ocean-continent boundary (OCB). The number of each solid blue line indicates figure number of seismic transects. Parallel red dots indicate a basement depression. 

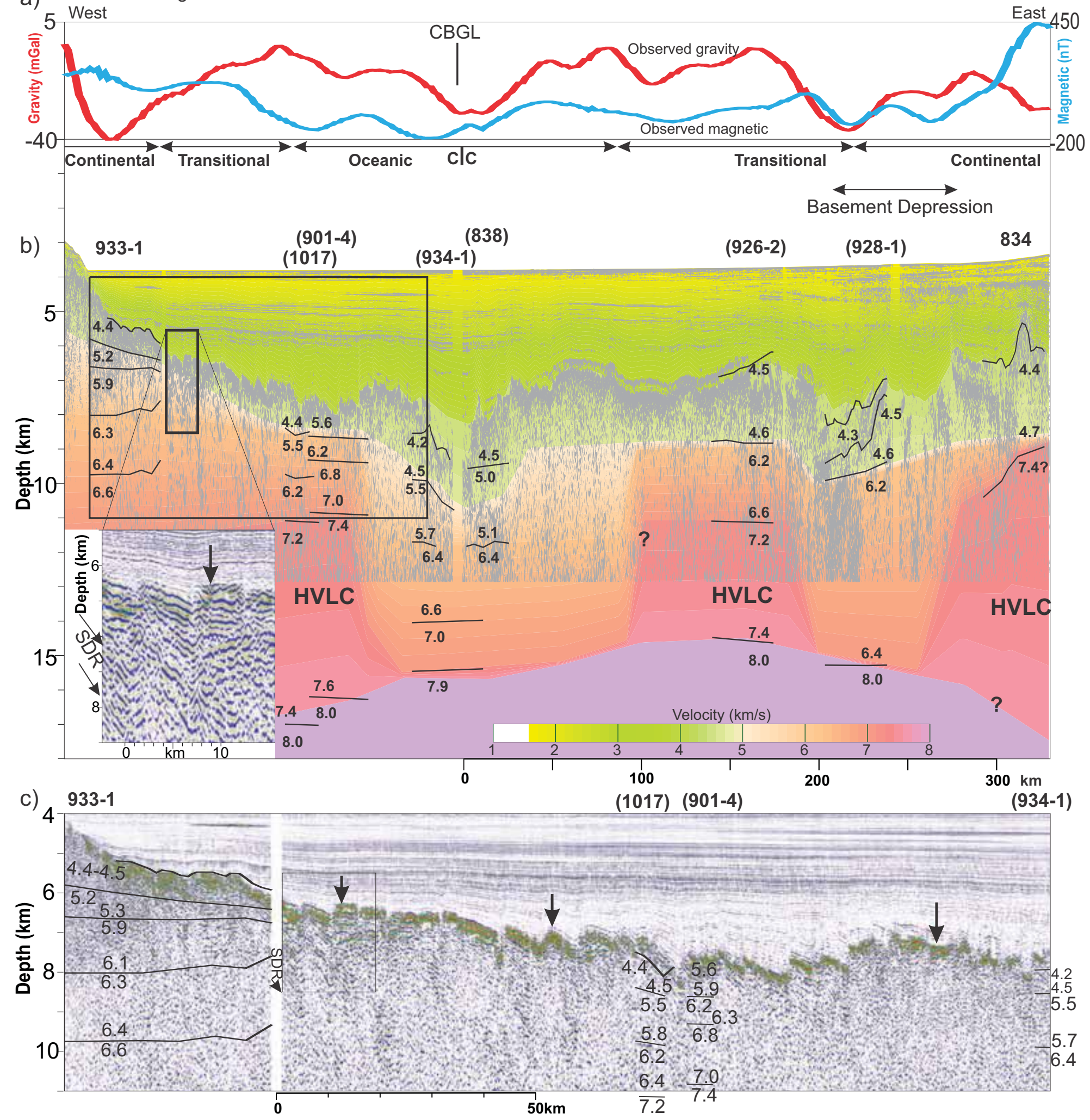

Figure 9. Seismic transect across northernmost Canada Basin. a) Observed magnetic and gravity anomalies (extracted from gridded maps in Figures 7 and 8; CBGL: Canada Basin gravity low. C|C indicates course change. b) Reflection profile (Hilbert transformed) converted to depth using a velocity model based on all available sonobuoy data along transect; sonobuoy labels are plotted on seafloor; brackets indicate offline stations. The time-depth conversion process includes: assign distance to each trace of reflection profile, digitize seafloor and basement in time domain, and perform time-depth conversion assuming a compaction-oriented exponential velocity function for sediments in central Canada Basin (region 3; Shimeld et al. 2016). Crustal velocity models are overlain as solid lines and labels show their corresponding velocities in km/s. HVLC: High velocity lower crust. SDR: Seaward dipping reflectors. Final crustal model is constructed in depth domain that in general matches all available sonobuoy data. The rectangular area marked on panel b) is enlarged in c) to show details (vertical exaggeration: 7.6:1). Vertical arrows indicate sedimentary base. 


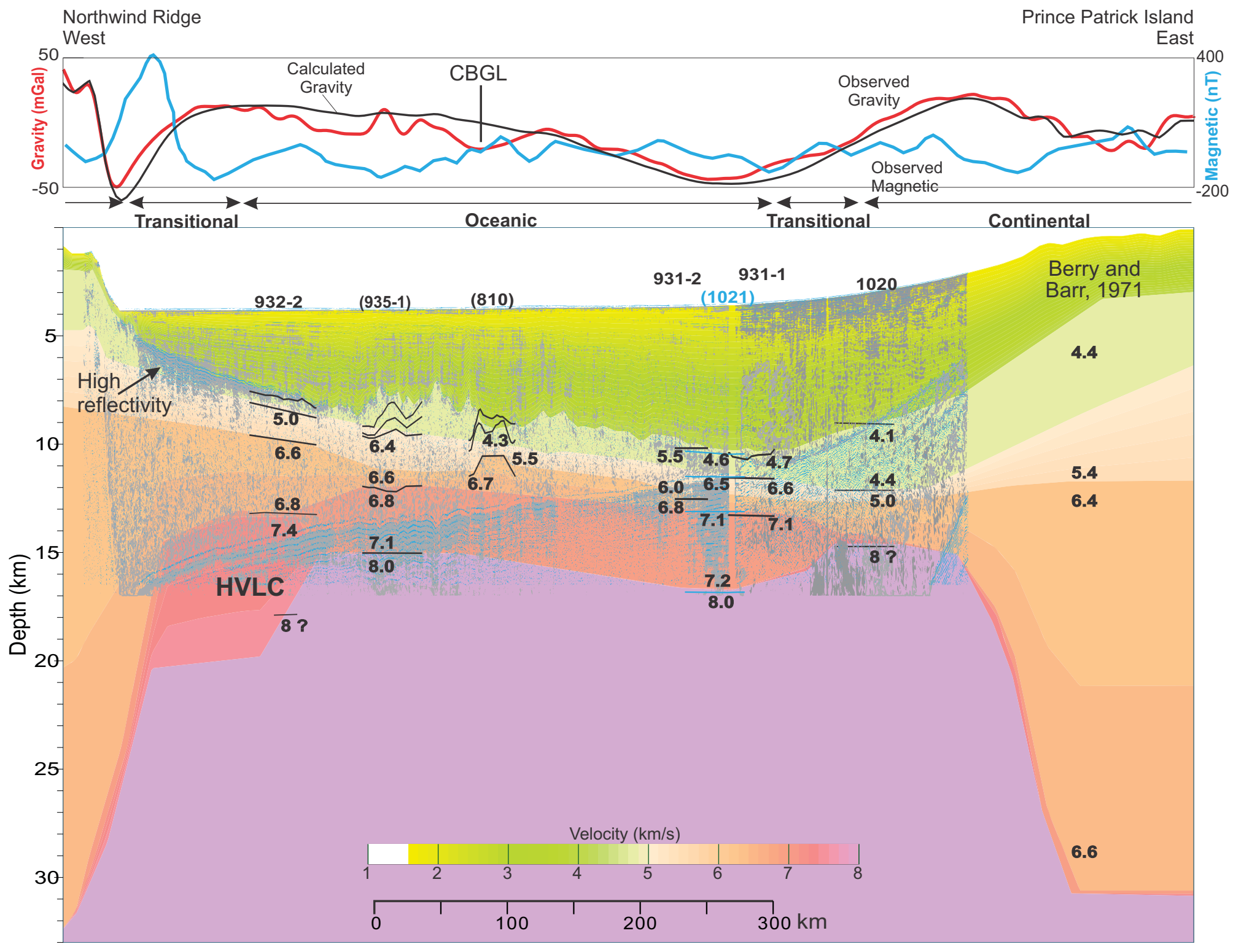

Figure 10. Seismic transect across central Canada Basin (see figure 1 for location). Top: magnetic (blue line) and gravity (red line) anomalies extracted from gridded data in Figures 7 and 8, with computed Free Air gravity anomaly (black line) for Moho constraint. Gravity computation used a velocity-density curve from Ludwig et al. (1970). Computed gravity is DC-shifted by $-712 \mathrm{mGal}$ and assumes a constant density of $3.3 \mathrm{~g} / \mathrm{cm} 3$ underneath the model. Bottom: velocity model overlain by depth-converted reflection profile. Sonobuoy 1021 is indicated in blue to contrast with adjacent instruments. See Figure 9b for more description. 

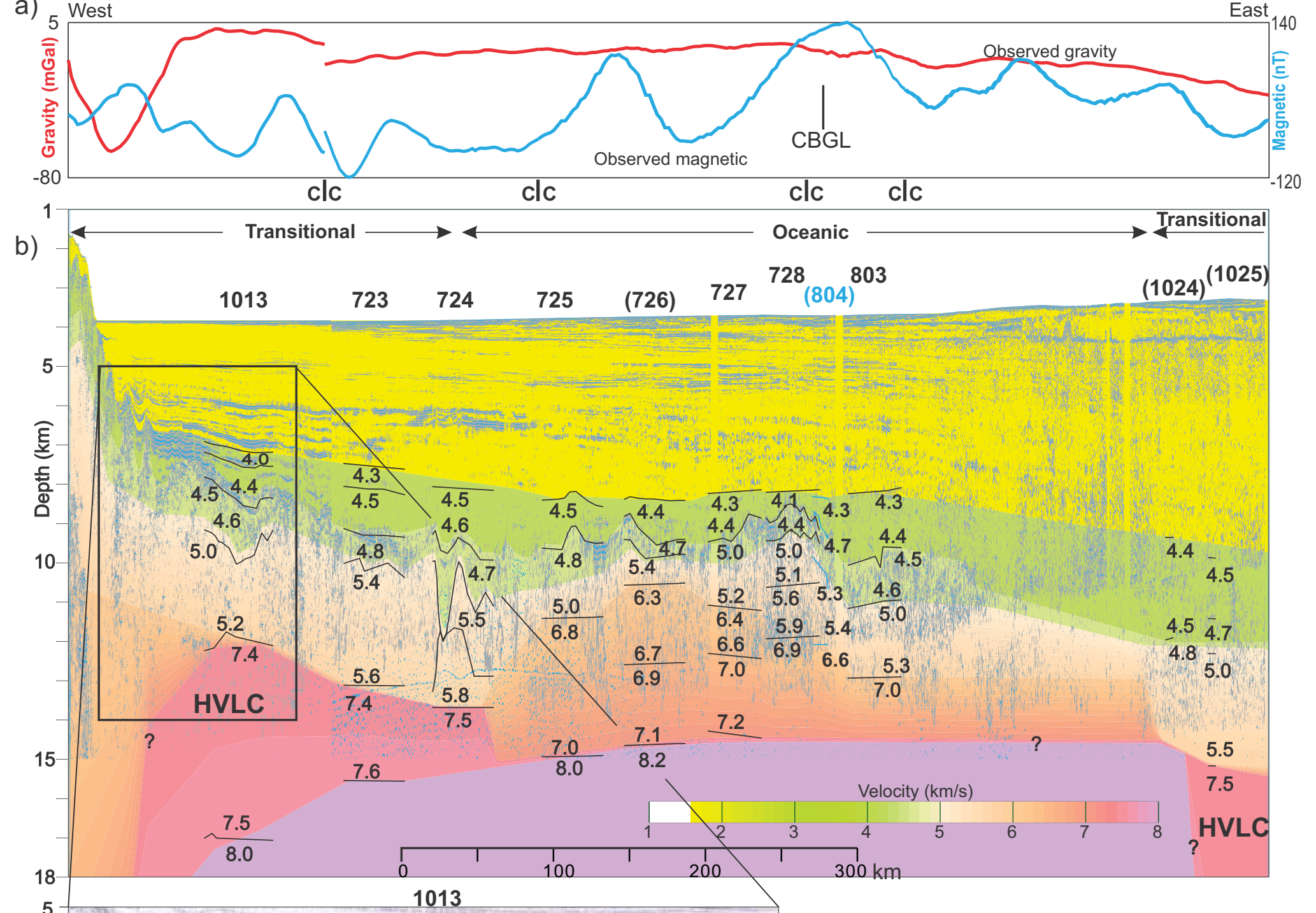

c)

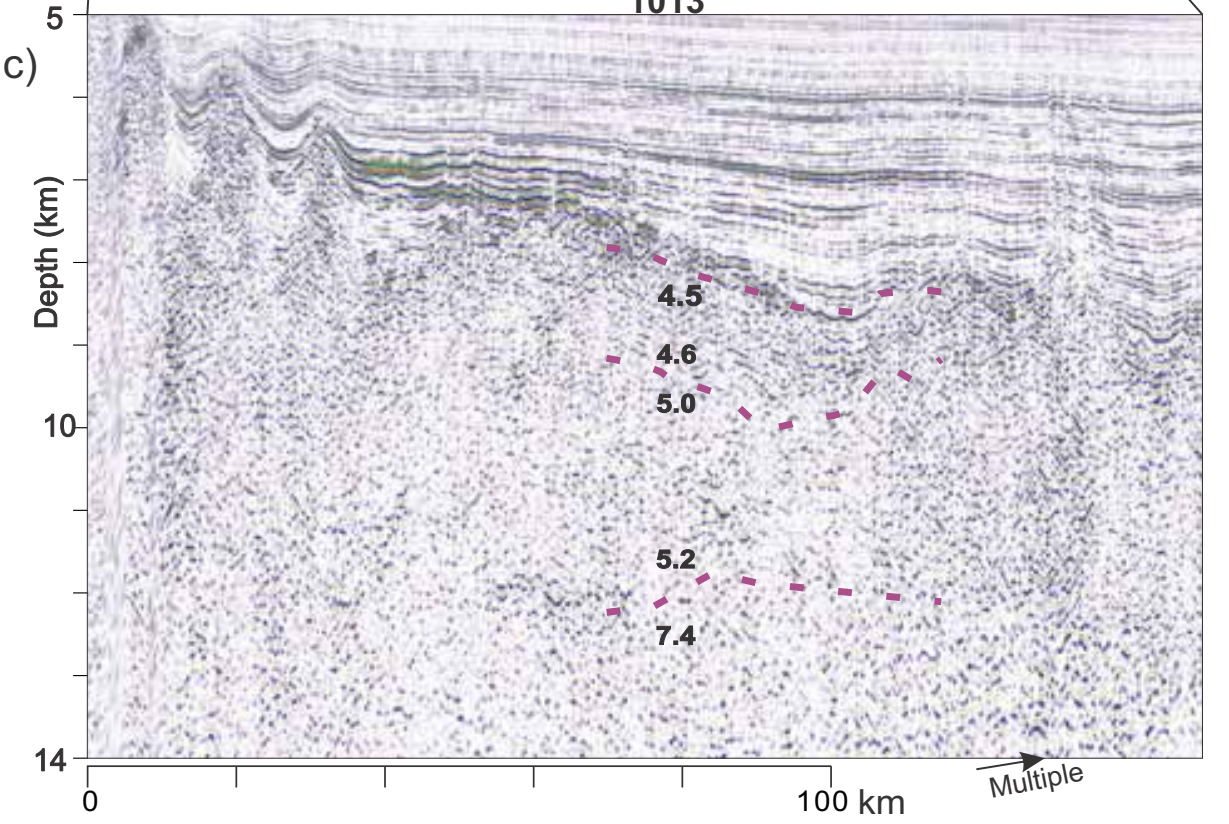

Figure 11. Seismic transect across southern Canada Basin (see Figure 1 for location). a) Magnetic (blue line) and gravity (red line) anomalies extracted from gridded data in Figures 7 and 8 . C $\mid C$ indicates course changes. b) Velocity model overlain by depth-converted reflection profile. Sonobuoy 804 is indicated in blue to contrast with adjacent instruments. The rectangular area marked on panel b) is enlarged in c) to show details of deeper reflectors coincident with $7.4 \mathrm{~km} / \mathrm{s}$ layer (vertical exaggeration: 11:1). See Figure 9b for more description. 


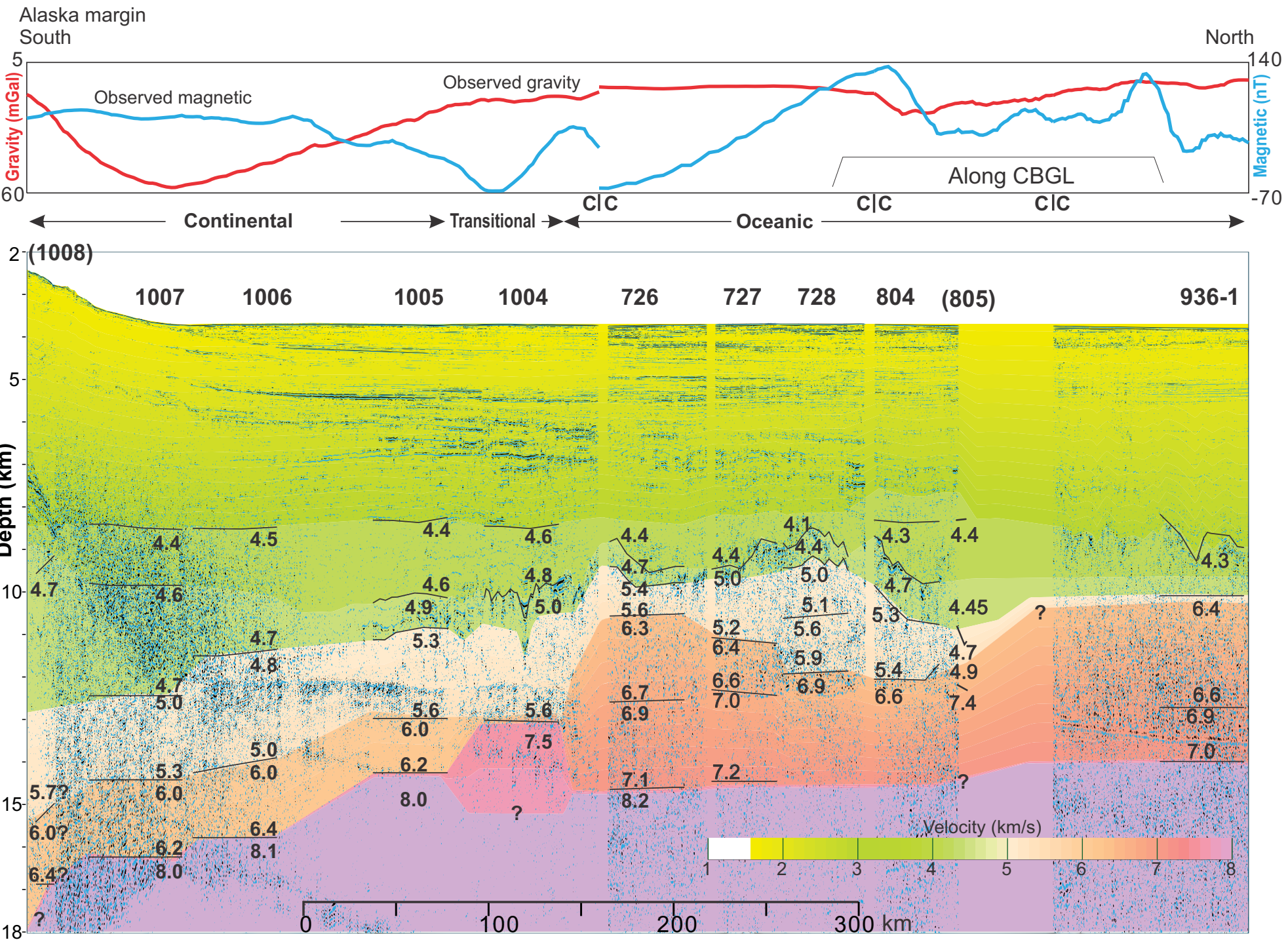

Figure 12. Seismic transect from Alaskan margin northward to nearly parallel to Canada Basin Gravity Low (CBGL). Top: magnetic (blue line) and gravity (red line) anomalies extracted from gridded data in Figures 7 and 8. Bottom: the transect combines 4 seismic profiles, crosses continental, transitional and oceanic crust, and shows distinctive features in crustal velocity structures as well as basement morphology. Reflection profiles are brute stack data converted to depth, with positive amplitudes plotted as grey and negative amplitudes as blue. See Figures $9 a$ and $9 b$ for more description. 


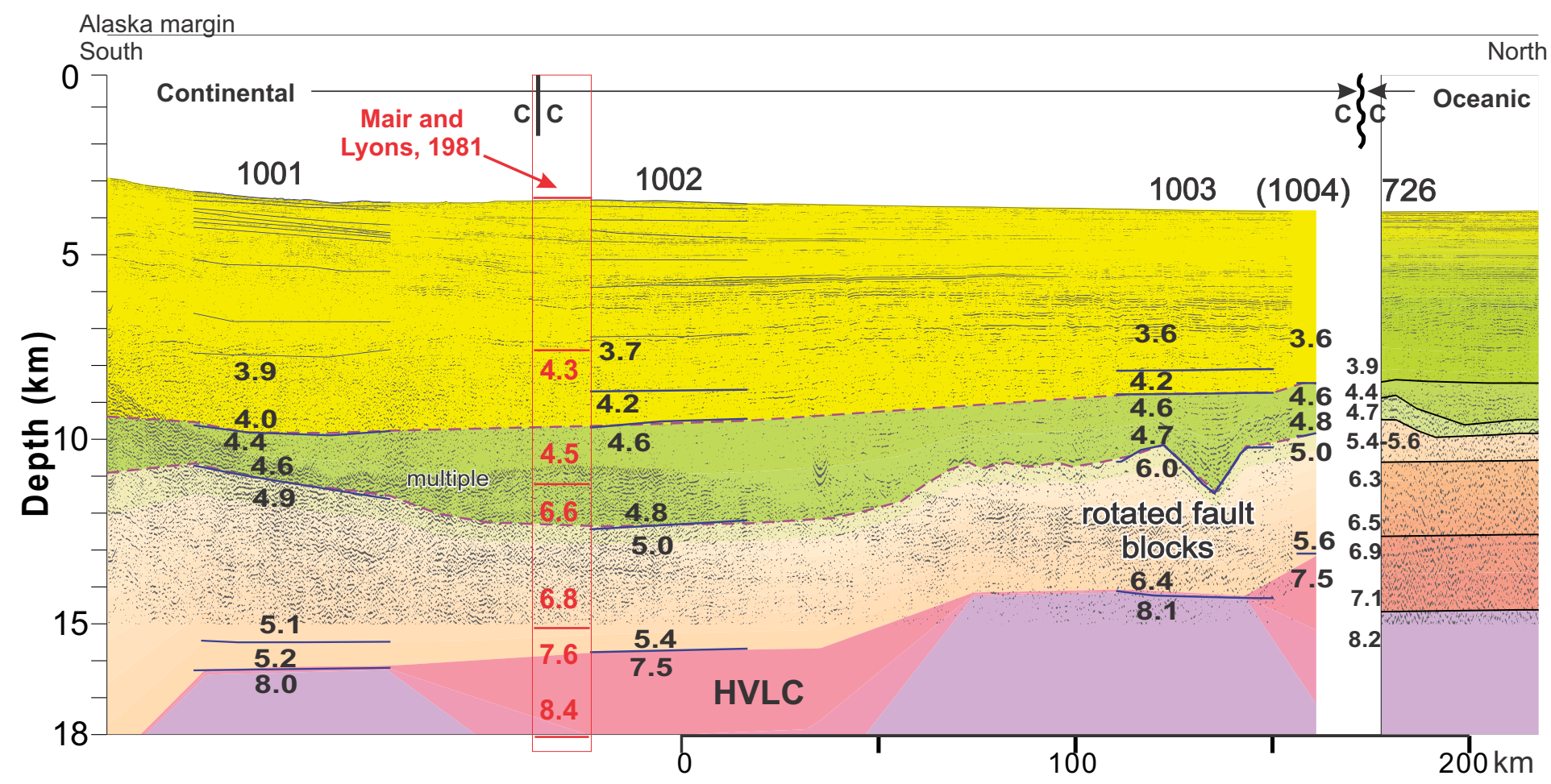

Figure 13. Seismic reflection profile that overlaps the refraction lines reported in Mair and Lyons (1981). The velocities reported by them are plotted in red and the velocities based on our sonobuoy data are in black. HVLC: high velocity lower crust. Sonobuoy 1002 is categorized as in transitional zone due to an observation of HVLC. But this region is in general continental because: crustal velocity is in the continental range; crust shows consistent reflection characters with regionally rotated fault blocks; and it is surrounded by typical continental crust in the vicinity of the shelf. 


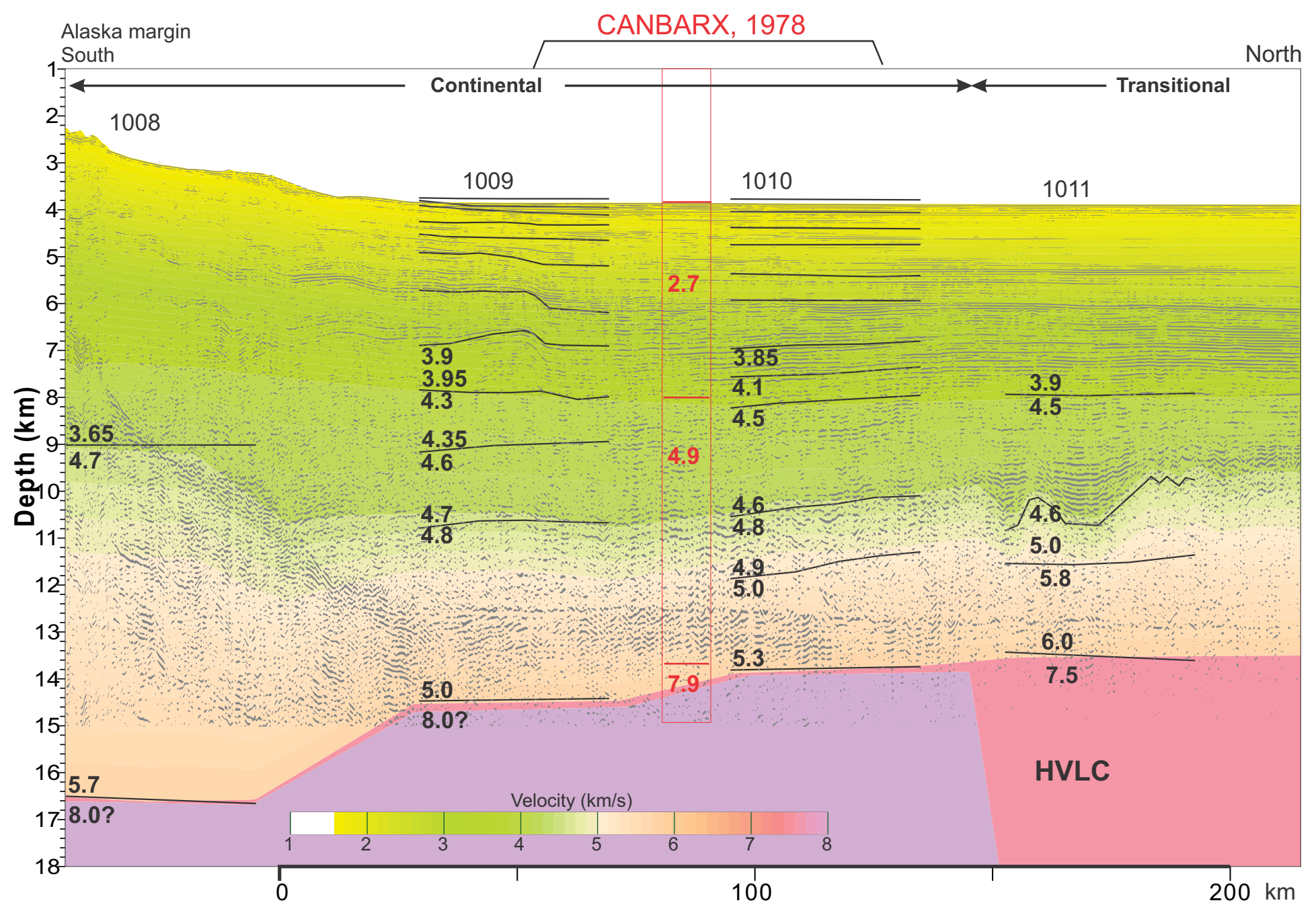

Figure 14. Previous refraction lines reported in Baggeroer and Falconer (1982) projected onto an adjacent profile of ours with sonobuoy results. Meaningful velocities reported by them are shown in red and labeled as CANBARX 78. See text for comparisons and interpretations. 

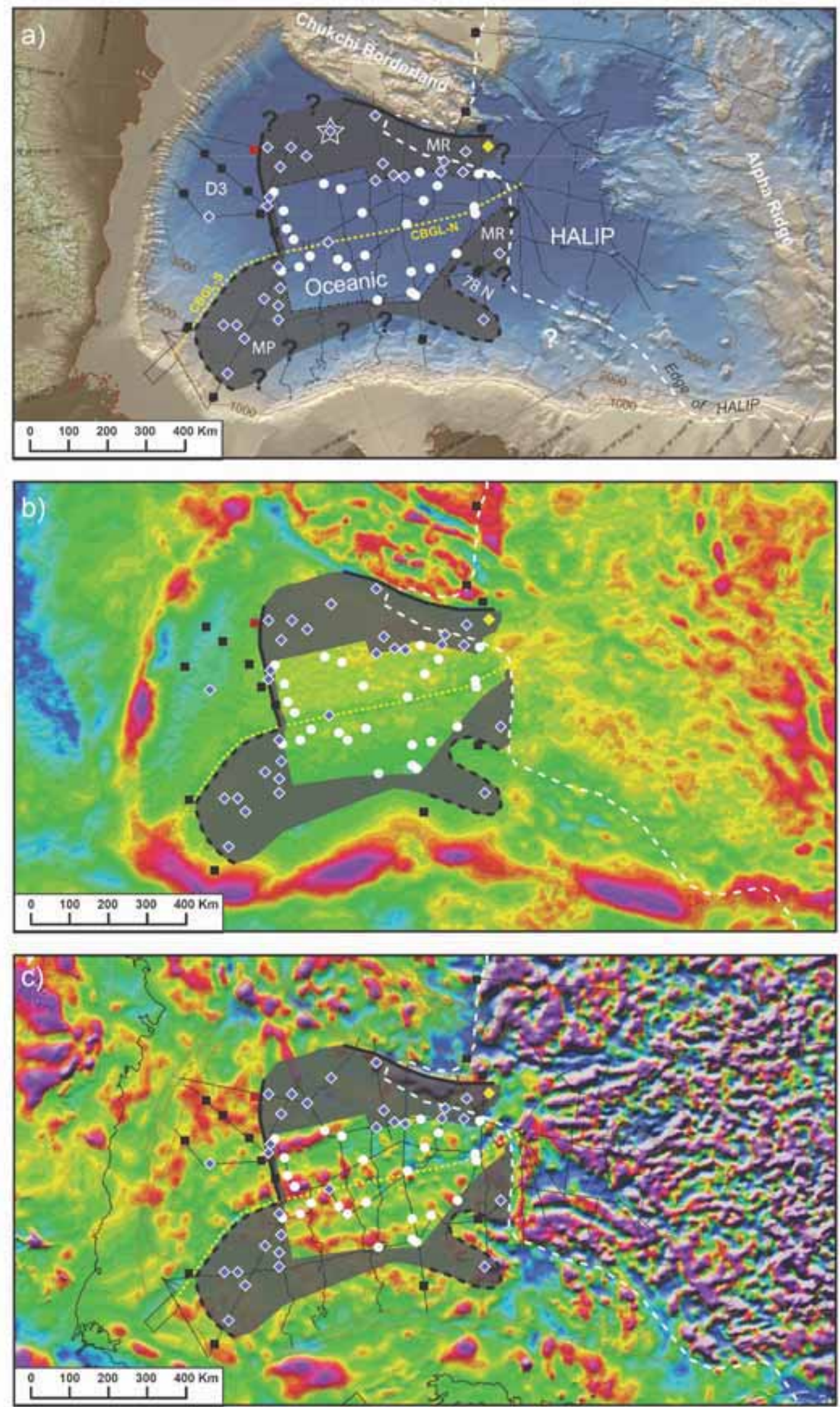

Figure 15. Interpreted distribution of crustal regions plotted on a) bathymetric, b) gravity and c) magnetic maps (for colour bars of scale see Figures 1, 8 and 7). The regions are based on combination of sonobuoy velocities, magnetic and gravity data, seismic reflection control and geological context. The area with gray shading is the ocean-continent transition. Its inner limit is the ocean-continent boundary. Star shows the position of sonobuoy 1013. Red and yellow dots indicate positions of refraction experiments by Baggeroer and Falconer (1982) and Jackson et al. (1995). CBGL-N: Canada Basin Gravity Low-North; CBGL-S: Canada Basin Gravity Low-South; MR: Magma Rich; MP: Magma Poor; HALIP: High Arctic Large Igneous Province. 